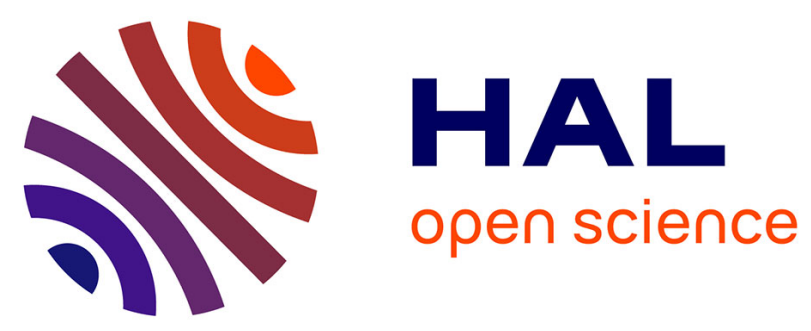

\title{
Systematic Review: Management options for primary sclerosing cholangitis and variant forms; IgG4-associated cholangitis and overlap with autoimmune hepatitis
}

\author{
Emma L Culver, Roger Chapman
}

\section{- To cite this version:}

Emma L Culver, Roger Chapman. Systematic Review: Management options for primary sclerosing cholangitis and variant forms; IgG4-associated cholangitis and overlap with autoimmune hepatitis. Alimentary Pharmacology and Therapeutics, 2011, 33 (12), pp.1273. 10.1111/j.1365-2036.2011.04658.x . hal-00633214

\section{HAL Id: hal-00633214 \\ https://hal.science/hal-00633214}

Submitted on 18 Oct 2011

HAL is a multi-disciplinary open access archive for the deposit and dissemination of scientific research documents, whether they are published or not. The documents may come from teaching and research institutions in France or abroad, or from public or private research centers.
L'archive ouverte pluridisciplinaire HAL, est destinée au dépôt et à la diffusion de documents scientifiques de niveau recherche, publiés ou non, émanant des établissements d'enseignement et de recherche français ou étrangers, des laboratoires publics ou privés. 


\begin{tabular}{l}
\hline Alimentary Pharmacology \\
\hline \& Therapeutics \\
\hline
\end{tabular}

\section{Systematic Review: Management options for primary sclerosing cholangitis and variant forms; IgG4-associated cholangitis and overlap with autoimmune hepatitis}

\begin{tabular}{|c|c|}
\hline Journal: & Alimentary Pharmacology \& Therapeutics \\
\hline Manuscript ID: & APT-0990-2010.R1 \\
\hline Wiley - Manuscript type: & Systematic Review \\
\hline $\begin{array}{r}\text { Date Submitted by the } \\
\text { Author: }\end{array}$ & 23-Mar-2011 \\
\hline Complete List of Authors: & $\begin{array}{l}\text { Culver, Emma; John Radcliffe Hospital Oxford, Gastroenterology } \\
\text { Chapman, Roger; John Radcliffe Hospital Oxford }\end{array}$ \\
\hline Keywords: & $\begin{array}{l}\text { Primary sclerosing cholangitis < Hepatology, Cholangiocarcinoma }< \\
\text { Hepatology, Inflammatory bowel disease }<\text { Disease-based, Liver } \\
\text { transplantation < Hepatology, Autoimmune liver disease }< \\
\text { Hepatology, Cholestatic liver disease }<\text { Hepatology }\end{array}$ \\
\hline
\end{tabular}


Title Page

Systematic Review: Management options for primary sclerosing cholangitis and its variant forms; IgG4-associated cholangitis and overlap with autoimmune hepatitis

E L Culver \& R W Chapman

\section{Author details;}

Dr Emma L Culver,

GastroenterologyRegistrar

John Radcliffe Hospital, Oxford, UK

Dr Roger W Chapman,

Consultant Hepatologist*

John Radcliffe Hospital, Oxford, UK

Contact email: roger.chapman.ox.ac.uk

\section{*corresponding author}

\section{Keywords;}

Primary sclerosing cholangitis, IgG4-associated cholangitis, overlap with autoimmune hepatitis, ursodeoxycholic acid, cholangiocarcinoma, inflammatory bowel disease, liver transplantation 


\begin{abstract}
Background: Primary sclerosing cholangitis (PSC) remains a challenging disease to manage. The main goals are prevention of disease progression and reduction of the increased cancer risk
\end{abstract}

\begin{abstract}
Aims: Toreview the management strategies for PSC and its variant formsbased on published studies.
\end{abstract}

Methods: Publications were identified using Pubmed, Medline and Ovid search engines.

Results:Distinguishing PSC from variants such as IgG4-associated cholangitis and overlap with autoimmune hepatitis is essential to guide treatment decisions. There is no proven efficacious medical treatment for PSC. Ursodeoxycholic acid has been disappointing in low and moderate doses, and potentially dangerous in higher doses, although its role and optimal dose in chemoprevention requires investigation. The novel bile acid 24-norursodeoxycholic acid has shown promise in mouse models; human trials are in progress.

\footnotetext{
Dominant strictures are optimally managed by dilatation and stenting to relieve obstructive complications, although exclusion of biliary malignancy is essential. Liver transplantation is the only proven therapy for those with advanced disease.

Cholangiocarcinoma remains the most unpredictable and feared complication. In highly selected groups, neo-adjuvant chemoradiation with liver transplantation seems
} 
promising but requires further validation. Screening for inflammatory bowel disease and surveillance for colorectal carcinoma should not be overlooked.

Conclusion: The effective management ofPSC and its variantsis hindered by uncertainties regarding pathogenesis of disease and factors responsible for its progression. Genome studies may help to identify further targets for drug therapy and factors leading to malignant transformation. 


\section{INTRODUCTION}

Primary sclerosing cholangitis (PSC) is a chronic progressive disorder characterised by inflammation, fibrosis and stricturing of intrahepatic and extrahepatic bile ducts, ultimately leading to liver cirrhosis. The aetiology is poorly understood; an immunemediated basis is suggested by lymphocytic portal tract infiltration and association with autoantibodies, human leukocyte antigen (HLA) haplotypes (HLA B8 DR3 and DQ2), other autoimmune diseases and inflammatory bowel disease ${ }^{1}$.It is not a classical autoimmune disease however, with a male predominance, ratio of 2 to 1 , and a poor response to immunosuppressive agents. There is strong evidence for genetic susceptibility from genome wide association analysis ${ }^{2}$.The current management of PSC is limited by uncertainties regarding its pathogenesis and factors responsible for its progression. In particular, the use of ursodeoxycholic acid in PSC has received much attention in light of recent studies, which will be discussed in this review, and the recognition of variant forms requiring careful diagnosis and individualised management.

\section{METHODS}

Publications were identified using pubmed, medline and ovid search engines to include controlled and randomized clinical trials, meta-analysis, practice guidelines, reviews and case reports in English language from January 1980 to January 2011 inclusive. Search words were primary sclerosing cholangitis (PSC), small duct PSC, IgG4-associated sclerosing cholangitis, autoimmune hepatitis overlap, ursodeoxycholic acid, cirrhosis and liver transplantation, inflammatory bowel disease, cholangiocarcinoma, and colorectal carcinoma. 2710 publications were identified, of which 974 met the search inclusion criteria. Abstracts with no full article available and any duplicate studies were further excluded from analysis.

\section{DIAGNOSIS}


The clinical presentation of PSC is variable; about 50\% are symptomatic at first presentation with abdominal pain, pruritis, fatigue, weight loss and fevers ${ }^{3}$. Portal hypertension and liver cirrhosis may manifest later in the disease. Asymptomatic patients are often identified after investigation of persistent cholestatic liver function or after a cholangiogram shows characteristic bile duct stricturing and segmental dilatation, once secondary sclerosing cholangitis and other causes of cholestasis are excluded $^{4}$. Laboratory investigation often reveals cholestatic liver biochemistry; an elevated alkaline phosphatase is the most common finding. Liver tests may be normal in $8.5 \%$ of cases and may fluctuate during the disease course ${ }^{3}$. Elevations in immunoglobulin $\mathrm{G}$ have been described in up to $60 \%$ of patients ${ }^{5}$. A wide range of non-specific autoantibodies can be detected in the serum; atypical perinuclear neutrophil cytoplasmic antibody has the strongest association with PSC, present in 33$88 \%$ of cases $^{6-7}$.

The diagnosis of PSCis usually established on the basis of a cholangiogram, demonstrating abnormal beading, irregularity and narrowing of the bile ducts. Magnetic resonance cholangiogram (MRC) is considered the gold standard as it is non-invasive, uses non-ionizing radiation and can delineate distal bile duct anatomy in the presence of proximal obstruction ${ }^{8}$. In a meta-analysis of 456 subjects, MRC had a high sensitivity and specificity for detection of PSC, 0.86 and 0.94 , respectively with positive and negative predictive ratios of 15.3 and 0.15 , respectively ${ }^{9}$. If MRC images are suboptimal, endoscopic retrograde cholangiopancreatography (ERCP) can be used, although it is usually reserved for sampling in the presence of a dominant stricture and for intervention to relieve biliary obstruction.Liver biopsy may show histological features diagnostic of PSC but only in one third of patients, and findings 
are often non-specific in early disease due to the patchy, focal nature of the disease ${ }^{10}$. In the presence of an abnormal cholangiogram, liver biopsy is considered to yield little extra information, except in diagnosing suspected variants of $\mathrm{PSC}^{11}$..

\section{VARIANTS OF PSC}

\section{Small-duct PSC}

This refers to a subgroup of patients who have clinical, biochemical and histological features compatible with PSC, but a normal cholangiogram. In the largest natural history study of 83 patients with small-duct PSC, only $22.9 \%$ of patients progressed to large-duct PSC over a median of 7.4 years (range $5.1-14$ years) ${ }^{12}$. The course of small-duct PSC was less aggressive, with significantly longer transplantation-free survival, 13 years versus 10 years $(95 \%$ CI 1.82-5.06; $\mathrm{P}<.0001)$, confirming earlier smaller studies ${ }^{13-15}$. Liver-related mortality, liver transplantation and post transplantation recurrence have been reported in small-duct PSC; however cholangiocarcinoma has only been described in those patients that progress to largeduct $\mathrm{PSC}^{12}$.

Diagnostic criteria for small-duct PSC remains to be defined, although a high-quality cholangiogram is mandatory to exclude PSC with isolated intra-hepatic distribution, and mutation analysis may be necessary to exclude other cholangiopathies such as $\mathrm{ABCB} 4$ deficiency causing compatible histological features ${ }^{16}$.Inflammatory bowel disease has been described in $50-88 \%$ of patients with small-duct PSC ${ }^{14-15}$. In patients with IBD and cholestatic liver enzymes, a normal high quality MRC scan should prompt liver biopsy and histological analysis for evidence of small-duct PSC. 
Management of patients with small-duct PSC is not well defined. In a longitudinal cohort study of 42 patients with small-duct PSC followed up for up to 24.9 years, the presence of IBD resulted in earlier diagnosis, but had no impact on long-term prognosis. UDCA therapy in both groups improved liver biochemistry over an average of 40 months $(\mathrm{p}<0.001)$, but had no effect on delaying disease progression (RR 0.95, CI 0.38-2.36) ${ }^{17}$. Liver transplantation is indicated for advanced liver disease, with a risk of recurrence in the transplanted liver. There are currently no agreed guidelines for surveillance of patients with small-duct PSC for the development of large-duct PSC.

\section{PSC with overlap features of autoimmune hepatitis}

This is an ill-defined immune-mediated disorder with histological features of autoimmune hepatitis (AIH) and cholangiographic findings typical of PSC. It has been described predominantly in children, adolescents and young adults ${ }^{18-19}$. The diagnostic criteria are not well defined.A retrospective diagnosis of 'PSC-AIH overlap syndrome' was established in $8 \%$ of 113 PSC patients from The Netherlands and $1.4 \%$ of 211 PSC patients from the United States, using the modified AIH score ${ }^{20-}$ ${ }^{21}$. Prospective analysis revealed an overlap syndrome in $17 \%$ of a cohort of 41 PSC patients from Italy, defined by a revised AIH score of over 15, anti-nuclear antibody or anti-smooth muscle antibody titre of at least 1:40, and characteristic histological abnormalities $^{22}$.Prevalence of AIH in adults with sclerosing cholangitis has been reported to vary from $1.7 \%$, when identified prospectively by MRC and liver biopsy and not including intrahepatic duct abnormalities associated with fibrosis score on biopsy, to $10 \%$ when identified prospectively on MRC and associated with a younger 
age, high ALP at baseline and bilirubin at the time of scan and lobular activity on initial biopsy ${ }^{23-24}$.

The development of PSC and AIH may be sequential in occurrence, thus in patients with PSC an elevation in serum transaminases should prompt a search for $\mathrm{AIH}$, and patients with $\mathrm{AIH}$, cholestasis or resistance to immunosuppressive therapy should raise suspicion of PSC ${ }^{25}$. UDCA and immunosuppressive therapy are often prescribed in combination in patients with PSC-AIH overlap syndrome, although there are no controlled studies evaluating this approach. Retrospective studies have suggested a benefit of corticosteroids in adult patients with PSC and AIH overlap features ${ }^{26}$. In a prospective Italian study, overlap patients treated with UDCA $(15-20 \mathrm{mg} / \mathrm{kg} / \mathrm{day})$, prednisolone $(0.5 \mathrm{mg} / \mathrm{kg} / \mathrm{day}$, tapered to $10-15 \mathrm{mg} / \mathrm{d})$ and azathioprine $(50-75 \mathrm{mg})$, showed a good biochemical response ${ }^{22}$.PSC-AIH overlap syndrome has a better prognosis than PSC, as predicted by the Mayo score, but poorer outcome than $\mathrm{AIH}^{19,22}$. Liver transplantation is indicated for advanced disease.

\section{IgG4-associated cholangitis}

Immunoglobulin G subclass 4-associated cholangitis (IAC) is a biliary disease of unknown immunopathogenesis, with cholangiographic features indistinguishable from PSC, but distinct histological findings and a dramatic response to corticosteroids $^{27}$. In the largest cohort of 53 IAC patients from the Mayo clinic, median age at diagnosis was 60 years in a predominantly male patient group (85\%), frequently presenting with obstructive jaundice ${ }^{28}$. IBD is less frequently associated with IAC than PSC, described predominantly in case reports and small series, although IgG4 positive plasma cells have been detected in colonic specimens in 
patients with autoimmune pancreatitis and IgG4-related colitis may mimic IBD ${ }^{29-30}$. Diagnostic criteria have been proposed for IAC based on characteristic histological and cholangiographic findings, elevations in serum $\operatorname{IgG} 4$, systemic organ involvement and response to corticosteroids ${ }^{28}$. These are still to be cross-validated in an independent cohort of patients.

It is important to differentiate IAC from PSC; elevated levels of serum IgG4 were found in $9 \%$ of 127 patients previously diagnosed with PSC in one series from the Mayo Clinic. Patients with elevated IgG4 had more severe biochemical parameters, higher Mayo risk score and a shorter time to transplantation suggesting a more severe disease course ${ }^{31}$. Patients with elevated IgG4 had more aggressive course pre and post transplantation $^{32}$. The relevance of these observations remains to be determined, although in the meantime cohorts of PSC patients should be scrutinised to detect patients with IAC, given the different management strategies and possible outcome. Dominant strictures of IAC may also mimic hilar cholangiocarcinoma (CCA), which must be rigorously excluded prior to initiation of treatment ${ }^{33}$. The importance of intrahepatic cholestasis and elevated serum IgG4, in the context of a normal cholangiogram, is still to be elucidated.

Corticosteroids result in resolution of jaundice, improved liver biochemistry, a reduction of serum IgG4 levels and reversal of strictures on cholangiogram in patients with IAC $^{28}$. Relapse has been documented in $40 \%$ of patients after completing an 11 week course of steroids in a retrospective study from the Mayo group; post-hoc analysis revealing strictures of the proximal extrahepatic and intrahepatic bile ducts were associated with a higher risk of relapse compared with those with strictures of 
the distal ducts, the extent of disease perhaps affecting long-term response $^{28}$.Similarly, corticosteroids can be used in the management of IgG4associated autoimmune hepatitis variant, which responds dramatically to steroids in the initial and maintenance phase of treatment with less relapse reported in a small retrospective study, although further studies are needed to confirm this ${ }^{34}$.Azathioprine at doses up to $2 \mathrm{mg} / \mathrm{kg} /$ day should be considered in those with proximal and intrahepatic stenoses and those that relapse during and/or after corticosteroid therapy. Rituximab, a monoclonal antibody directed against CD20 antigen on B lymphocytes, has been used successfully in a patient unresponsive to other immunosuppressive agents $^{35}$. Natural history and prognosis has not been adequately defined.

\section{MANAGEMENT OF PSC}

The main goals of therapy are retardation and reversal of the disease process and management of progressive disease and its complications. Prognostic models have limited value in the individual patient because of disease variability and the presence of confounding factors, such as biliary sludge and stones, main duct strictures, and CCA. The Mayo risk score provides the most valid survival information in early PSC in patient cohorts ${ }^{36-37}$. Although the course is variable, PSC is generally progressive and leads to biliary cirrhosis. The 10 -year survival was approximately $65 \%$ in a population study from the United States ${ }^{38}$. A median transplantation-free survival of 18 years was reported in a Dutch population ${ }^{39}$. Liver failure and CCA are the two major complications that affect survival, malignancy becoming the most important cause of death over the last decade ${ }^{40}$.

\section{SPECIFIC MEDICAL THERAPY}


The search for an effective medical treatment for PSC has been hindered by uncertainties regarding the pathogenesis of disease and factors responsible for its progression. There is no medical therapy to date that conclusively alters the natural history of disease.Ursodeoxycholic acid (UDCA), a hydrophilic dihydroxy bile acid, is the most extensively studied medical therapy for PSC. It is believed to exert a number of beneficial effects in chronic cholestatic conditions, including direct and indirect cytoprotection, stimulation of hepatobiliary secretion, immunomodulation and protection of hepatocytes from bile-induced apoptosis ${ }^{41}$.The relative importance of each in alleviating cholestasis remains unclear. UDCA may also have a chemoprotective effect; inhibiting proliferation of tumour cell lines in vitro ${ }^{42}$.

\section{UDCA in cholestasis and disease progression}

A number of trials have attempted to address the clinical efficacy of UDCA in thecontext of PSC, summarised in Table 1. Early pilot studies of UDCA, in doses ranging from 10 to $15 \mathrm{mg} / \mathrm{kg} / \mathrm{day}$, demonstrated biochemical and in some, histological improvement ${ }^{43-46}$. A larger double-blind placebo-controlled study of UDCA 13$15 \mathrm{mg} / \mathrm{kg} /$ day in 105 patients with PSC showed an improvement in liver biochemistry, but no improvement in symptoms, histological progression, development of portal hypertension or liver transplantation after 2 to 5 years of therapy ${ }^{47}$. Further analysis, suggested a trend towards increased transplant-free survival in the treated group ${ }^{48}$.

Higher doses of UDCA, $20 \mathrm{mg} / \mathrm{kg} /$ day, were evaluated in a double-blind placebocontrolled trial of 26 patients, showing improvements in liver biochemistry, cholangiographic appearance and histological progression, but no effect on survival after 2 years of therapy ${ }^{49}$. A larger multi-centre randomised study of UDCA at 17-23 
$\mathrm{mg} / \mathrm{kg} / \mathrm{day}$ in 219 patients demonstrated a non-significant trend towards increased survival in the UDCA treated group compared to placebo over 5 years, although it was insufficiently powered to achieve statistical significance and biochemical response was poor suggesting an issue with drug compliance ${ }^{50}$.

A randomised dose-ranging trial in 30 PSC patients was conducted to look at outcomes of higher doses of UDCA over 2 years; the low dose $(10 \mathrm{mg} / \mathrm{kg} / \mathrm{day})$ and the standard dose $(20 \mathrm{mg} / \mathrm{kg} /$ day $)$ showed a trend towards improved survival, and the high dose $(30 \mathrm{mg} / \mathrm{kg} / \mathrm{d})$ significantly improved projected survival compared with the Mayo risk score ${ }^{51}$. However, a multi-centre placebo-controlled randomised study using high dose UDCA, $28-30 \mathrm{mg} / \mathrm{kg} /$ day in 150 patients over 5 years was discontinued early as the patients randomised to UDCA, despite having improvement in liver biochemistry, were significantly more likely to reach the primary outcome of death, liver transplantation or development of varices compared with the placebo group, especially in more advanced disease ${ }^{52}$. The reason for this remains unclear; the authors postulating that high-dose UDCA may cause direct hepatocyte necrosis in patients with advanced PSC with downstream biliary obstruction due to strictures, or that high-dose UDCA may lead to increased levels of hepatotoxic lithocholic acid, produced in the right colon ${ }^{53-54}$. A subsequent analysis of the serum bile acid profile of 56 patients in the high dose UDCA group has so far demonstrated significant expansion of the total serum bile acid pool, including lithocholic acid compared to the placebo group $(\mathrm{P}=0.001)^{55}$. Further analysis of this data is awaited. 
To date, many studies have enrolled patients with advanced stage disease; the role of UDCA much earlier in the disease process may have a different impact but has not been fully assessed.

\section{UDCA in chemoprevention}

\section{Colorectal carcinoma in patients with PSC and IBD}

Retrospective studies support a role for UDCA in reducing the risk of colorectal carcinoma (CRC) in patients with PSC and UC.A cross-sectional study of 59 PSC patients with UC undergoing colonoscopic surveillance found a significantly reduced prevalence of colonic dysplasia in patients taking UDCA (OR 0.18, 95\% CI 0.050.61), although there was an exceptionally high rate of dysplasia in the control group $^{56}$. In a follow-up of 52 patients with PSC and UC, who participated in a randomised placebo-controlled trial of UDCA, over 355 patient-years, the UDCAtreated patients had a significant reduction in the relative risk of developing CRC or dysplasia(RR $0.26,95 \%$ CI $0.06-0.92, p=003)^{57}$. A historical cohort study, comparing 28 patients with PSC and UC treated with UDCA with 92 patients not treated with UDCA, reported a trend towards a lower risk of colonic dysplasia and neoplasia and a significantly lower mortality in those treated with UDCA ${ }^{58}$. However, there have been no prospective controlled trials investigating the role of UDCA in chemoprevention, and the most effective dose is still to be elucidated.

\section{Cholangiocarcinoma in patients with PSC}

Observational studies provide limited evidence for a beneficial effect of UDCA on the risk of developing CCA. In a single controlled study of 150 patients with PSC treated with UDCA over a median of 6.4 years, a lower annual incidence rate of CCA 
(3.3\%)was reported in PSC patients treated with UDCA, this rate decreasing with length of treatment $(0.59$ in year 0 to $2.5,0.58$ in years 2.5 to 8.5 , none in years 8.5 to $18)^{59}$. In a study of 255 PSC patients listed for liver transplantation over a period of 11 years, the absence of UDCA was an independent risk factor for the development of hepatobiliary malignancy ${ }^{60}$. However, two randomized placebo-controlled UDCA trials with 219 and 150 PSC patients, did not observe a difference in CCA development in the UDCA and placebotreated groups ${ }^{50,52}$. Thus, there is insufficient evidence to support the use of UDCA for chemoprevention of CCA at this time.

\section{4-norursodeoxycholic acid}

An alternative novel bile acid, 24-norursodeoxycholic acid, an inhibitor in the formation of toxic bile, has been shown to have antifibrotic, anti-inflammatory and antiproliferative effects in a knockout multi-drug resistance protein 2-null (Mdr2-/-) mouse model of cholangitis and biliary fibrosis, reversing sclerosing cholangitis within 4 weeks of treatment ${ }^{61-62}$. Human studies are currently in progress.

\section{Other therapies (summarised in Tables 2-4)}

Studies of glucocorticoids and immunosuppressive agents have been disappointing, none demonstrating convincing evidence of benefit and a few associated with significant side effects ${ }^{63}$. Antifibrotic agents, anti-TNF monoclonal antibodies, and other agents with TNF-alpha antagonising effects have been evaluated with no overall benefit.Pilot studies of combination therapy have been encouraging but inconclusive, conducted in small number of patients treated for short periods of time, with end points focussing on improvements in biochemistry and Mayo risk score. There is no data evaluating survival or time to liver transplantation. The presence of PSC variants 


\section{Dominant strictures}

A dominant stricture has been defined as 'a stenosis with a diameter of less than or equal to $1.5 \mathrm{~mm}$ in the common bile duct or of less than or equal to $1 \mathrm{~mm}$ in the right and/or left hepatic duct ${ }^{64}$. The majority of patients with advanced PSC develop dominant stenoses of major bile ducts; in one of the largest studies of 125 patients with PSC, $45 \%$ had a dominant stricture of the common bile duct and/or right or left hepatic ducts ${ }^{65}$. Furthermore, patients who do not have a stricture at diagnosis may develop one over time; a study of 106 PSC patients reported 40\% developed a dominant stricture over five year follow-up ${ }^{66}$. Dominant strictures are associated with a reduced transplant-free survival; in one prospective study transplantation-free survival at 18 years was $25 \%$ compared with $73 \%$ in those with or without dominant stenoses, respectively $(\mathrm{p}=0.011)^{67}$.

Given their relative frequency, stenotic lesions are more likely to be benign than malignant. However, the presence of a dominant stricture should always raise the suspicion of CCA, which may develop in $10-15 \%$ of patients with PSC $^{68}$.Endoscopic 
brushings and/or biopsy and further imaging of the biliary system are usually required to differentiate the two.

Interventions to decompress the biliary tree aim to reduce obstructive complications and prolong transplant-free survival, via an endoscopic, radiological or surgical approach. UDCA treatment has not been shown to prevent the development of dominant stenoses in uncontrolled trials, although it has not been evaluated as an independent variable ${ }^{66}$.

\section{Sphincterotomy, dilatation and stenting}

Endoscopic dilatation of dominant biliary strictures and drainage by sphincterotomy and stenting, may lead to symptomatic, biochemical and radiological improvement in selected cases. The sphincter of Oddi may itself become sclerosed, contributing to biliary obstruction. Sphincterotomy alone has been shown to improve biochemical parameters in small uncontrolled studies; however its predominant role in PSC is to facilitate dilatation, stent placement or stone extraction ${ }^{69-70}$. Balloon dilatation has been shown to be effective alone in the treatment of dominant strictures ${ }^{71-72}$. Repeated balloon dilatation and stenting has been assessed in retrospective studies of PSC patients taking UDCA, suggesting a trend towards a benefit when comparing jaundice, cholangitis, biochemicalcholestasis, transplantation and actuarial survival rates compared with predicted Mayo risk score ${ }^{73-74}$. The optimum method and frequency of dilatation remains to be defined.

Retrospective studies evaluating short-term and long-term stenting for dominant strictures have demonstrated improvements in symptoms, cholestasis and rates of 
cholangitis ${ }^{75-76}$. Prospective uncontrolled trials have suggested transplant-free survival advantage of combined UDCA and endoscopic balloon dilatation and/or biliary stent placement, although the relative contribution of each is difficult to ascertain ${ }^{66}$. Long term outcome has yet to be evaluated in randomised controlled trials.Complications from endoscopic therapy have been reported in 7 to $20 \%$ of PSC patients ${ }^{73,77}$. Studies comparing the role of balloon dilatation with stentinghave demonstrated similar efficacy but lower complications rateswith balloon dilatation alone,especially cholangitis ( $18 \%$ vs. $50 \%$, respectively $)^{71}$. Stenting is therefore usually reserved for strictures that are refractory to dilatation.

The percutaneous approach is reserved for those patients with proximal dominant strictures and complex biliary anatomy, often after repeated and/or failed attempts at endoscopic intervention. There are no randomised studies comparing percutaneous transhepatic cholangiography (PTC) with ERCP in stricture management in modern day practice. It is generally accepted, however, that the percutaneous approach is associated with higher morbidity ${ }^{78-79}$.

\section{Biliary surgery for strictures}

Surgery is considered in selected patients without cirrhosis, who have marked cholestatsis or recurrent cholangitis due to focal extra-hepatic or hilar strictures, which are not amenable to endoscopic or percutaneous dilatation ${ }^{80}$. In those requiring liver transplant, prior biliary surgery may lead to a longer operation time, greater intraoperative blood loss and high incidence of biliary complications post transplantation, when compared to those with no history of biliary surgery ${ }^{81-83}$. In those with cirrhosis, 
biliary surgery should be avoided as it is associated with high morbidity and mortality.

Resection of the extra-hepatic biliary stricture and Roux Y hepaticojejunostomy, with or without operative stent insertion,may be considered for selected non-cirrhotic PSC patients ${ }^{84}$. It is associated with a readmission-free rate from cholangitis of $57 \%, 83 \%$ and $60 \%$ at 3,5 and 10 years, respectively ${ }^{85}$. However, there is a risk of postoperative infection and scarring in the porta hepatis, which may complicate future transplantation $^{86}$. Biliary bypass by cholangio-enterostomy is infrequently the operation of choice, as most dominant strictures are hilar and intra-hepatic duct involvement limits the access and quality of ducts for bypass ${ }^{87}$. There is no conclusive evidence that surgical intervention altersthe natural history or progression of liver disease in patients with PSC.

\section{Bacterial cholangitis}

Cholangitis can occur in PSC patients with dominant or tight biliary strictures, coexisting bile duct stones, and in those undergoing endoscopic or percutaneous interventions or surgical exploration. It may be the first presentation of PSC in $6.1 \%$ of patients ${ }^{88}$. Recurrent and severe cholangitis may have a role in disease progression. Short courses of antibiotics are often insufficient to eradicate bacteria in the context of an obstructed system; therapeutic drainage in addition is considered more effective ${ }^{89}$. The presence of bacteria in the bile was not associated with reduced survival in one prospective non-randomised study, if stenoses were opened endoscopically and infection was adequately treated with antibiotics ${ }^{67}$. Patients with recurrent bacterial cholangitis may have small benefits from prophylactic long term antibiotics, which 
may be rotated to reduce bacterial resistance. Routine bile collection for microbiological analysis during cholangiography may help to define sensitivity of bacteria and guide antibiotic management ${ }^{90}$. In PSC patients with refractory severe bacterial cholangitis, but otherwise preserved liver function, transplantation may be indicated $^{91}$.

\section{Malignancy}

PSC is associated with an increased risk of hepatobiliary malignancy, particularly CCA. In a large Sweedish cohort of 604 PSC patients, $44 \%$ of deaths were due to malignancy; $13.3 \%$ due to hepatobiliary carcinoma ${ }^{92}$. Guidelines for screening and surveillance of malignancy in PSC are poorly defined and depend on the individual tumour.

\section{Cholangiocarcinoma}

This may present as an intra-hepatic focal carcinoma or more commonly as a ductal infiltrating desmoplastic lesion. CCA has a cumulative lifetime incidence of 10-30\% in patients with $\mathrm{PSC}^{93}$. It is found synchronously in 20-30\% and within one year of diagnosis in $50 \%$, the yearly developmental rate being 0.5 to $1.5 \%$ thereafter $^{92,94-96}$. There is no clear association between the duration of PSC and the development of CCA; however the presence of cirrhosis may be associated with an increased risk ${ }^{97-98}$. Deterioration in performance status, biochemical parameters or evidence of a dominant stricture on cholangiogram raises suspicion of CCA, although these may also be manifestations of progressive liver disease. Anatomic location of CCA influences the ease of diagnosis; hilar tumours causing earlier biliary obstruction than small or peripheral intrahepatic lesions ${ }^{99}$. Differentiating benign and malignant 
strictures is challenging, currently based on a combination of imaging modalities such as MR imaging and multi-slice spiral computer tomography (CT), in addition to endoscopic evaluationwithbrush cytology and/or biopsies of stenotic lesionsprior to any intervention ${ }^{100-101}$. The specificity of positive brush cytology is close to $100 \%$ but sensitivity is low in most centres (17 to $73 \%$ ); a negative sample not excluding malignancy ${ }^{102-103}$. Digital image analysis and fluorescence in situ hybridisation may increase the diagnostic yield of cytology further ${ }^{104-105}$. Regular brushing of dominant strictures with cytological analysis to detect early neoplastic transformation is adopted by some centres.

There is no reliable screening test for CCA in asymptomatic patients with PSC. In those who are symptomatic, serum Ca19-9 levels of $>130 \mathrm{U} / \mathrm{mL}$ have been reported to have a sensitivity of $79 \%$ and a specificity of $98 \%$ for presence of CCA, although this often identifies advanced unresectable CCA which limits its use ${ }^{106}$. Some clinicians screen asymptomatic patients with annual serum Ca19-9 levels and crosssectional imaging of the hepatobiliary system, although this requires validation ${ }^{100,107}$. In a study of 230 PSC patients, ultrasound, CT and MRI yielded a positive predictive value of $48 \%, 38 \%$ and $40 \%$, respectively in identification of $\mathrm{CAA}^{100}$. Endoscopic ultrasound with fine needle aspiration of hilar structures and lymph nodes may aid in diagnosis and staging ${ }^{108-109}$. The role of FDG-PET is controversial, as inflammation can yield false positives in patients with PSC.

The overall prognosis of patients with PSC complicated by CCA is poor, median survival of 5 to 11 months $^{110}$. Curative extensive surgical resection of early CCA gives 3-year survival rates of 20 to $40 \%$, but local recurrence is common due to micro 


\section{Gallbladder polyps and carcinoma}

Gallbladder abnormalities have been described in $41 \%$ of PSC patients in one large retrospective series ${ }^{118}$. Gallbladder dysplasia, adenoma and carcinoma have all been described in PSC patients, with a cumulative lifetime incidence of $2 \%{ }^{92}$. Gallbladder mass lesions in PSC frequently (>50\%)represent adenocarcinomas, independent of their size $\mathrm{e}^{119-120}$..A recent study reported a statistically significant association between hilar and/or intra-hepatic biliary neoplasia and gallbladder neoplasia, suggesting a 'field defect' in the biliary tree in $\mathrm{PSC}^{121}$. Given the high risk of malignancy of gallbladder polyps in PSC, cholecystectomy is advocated for gallbladder lesions of any size in both European and American practice guidelines ${ }^{64,122-123}$. Annual ultrasound surveillance of the gallbladder has been recommended to detect early abnormalities $^{123}$. 


\section{Pancreatic carcinoma}

The risk of pancreatic carcinoma in patients with PSC has been described in a Sweedish cohort as 14-fold increased, when compared to a matched-control population $^{92}$. This risk is lower in comparison to other hepatobiliary malignancy in PSC. There is currently no recommended screening for pancreatic disease.

\section{Hepatocellular carcinoma}

Cirrhotic patients with PSC are at risk of developing hepatocellular carcinoma (HCC). The cumulative lifetime incidence of HCC in PSC patients is $2 \%{ }^{124}$. Screening for HCC in cirrhotic patients, by 6 monthly abdominal imaging and/or alpha-feta protein levels, should follow guidelines as for other cirrhotic chronic liver diseases ${ }^{125}$.

\section{EXTRAHEPATIC COMPLICATIONS}

Extra-hepatic complications of PSC include symptomatic pruritis and fatigue, malabsorption and fat-soluble vitamin deficiency, and the development of metabolic bone disease. The management of these complications has been described in detail in the recent European guidelines and is summarised in Table $5^{123}$.

\section{INFLAMMATORY BOWEL DISEASE}

\section{IBD in patients with PSC}

PSC is strongly associated with IBD, with a reported prevalence in Northern Europe and Northern America of $60-80 \%{ }^{141-142}$. IBD often precedes the development of PSC, although it may be diagnosed at any time during its course, even de novo after liver transplantation $^{143-144}$. Ulcerative colitis (UC) accounts for the majority (80\%) ofcases, while $10 \%$ have Crohn's disease (CD) and 10\% have indeterminate colitis ${ }^{145}$. 
PSC patients who have an ileal pouch anal anastomosis(IPAA) after colectomy for UC have an increased risk of pouchitiscompared to those with UC alone, which should be considered when planning colectomy for aggressive disease ${ }^{148}$. Patients with an ileostomy after proctocolectomy can develop peristomal varicies, which can bleed recurrently and be difficult to manage ${ }^{149}$. Local treatments with injection of sclerosants, venous ligation and surgical revision are usually unsuccessful, and portosystemic shunting or liver transplantation may be necessary to control this complication.

\section{PSC in patients with IBD}

PSC is diagnosed in between 2.4 to $7.5 \%$ of patients with UC, and $3.4 \%$ with $\mathrm{CD}^{143,150}$. It can be detected at any time during its course, and may present several years after proctocolectomy.The prevalence of PSC is higher in those with substantial $(5.5 \%)$ than distal colitis $(0.5 \%)^{151}$. Patients with advanced PSC and IBD are more likely to be male, asymptomatic on presentation, and have both intra and extrahepatic 
bile duct strictures ( $82 \%$ versus $46 \%$ ) compared to those with PSC alone ${ }^{153}$. There is no routine screening of IBD patients for the presence of PSC.

\section{Colorectal dysplasia and carcinoma}

Patients with PSC and UC are at a greater risk of developing colonic dysplasia and carcinoma than those with UC alone; a meta-analysis of 11 studies concluded the risk was increased by approximately fourfold (OR 4.26; 95\% CI 2.80 to 6.48$)^{153}$. The absolute cumulative risk seems toincrease with disease duration; CRC risk of 9\%, $31 \%, 50 \%$ respectively, after 10, 20, 25 years in patients with PSC and UC, compared to $2 \%, 5 \%$ and $10 \%$ in those with UC alone ${ }^{154}$. The reason for this is unclear, although it is speculated that secondary bile acids play a role in the carcinogenesis of the colorectal mucosa in $\mathrm{PSC}^{155}$. This is supported by the observation that right-sided cancers are more common in patients with UC and PSC (76\%), compared to UC alone $^{156-157}$. Patients with PSC and UC continue to have a high risk of CRC after transplantation, with a four-fold increased risk compared to pre-transplantation estimates in one study, perhaps as a result of immunosuppressive medications or the duration of colitis ${ }^{158}$.

Diagnosisof IBD has implications for follow-up and dysplasia/cancer surveillance. PSC patientswith ulcerative or Crohn's colitis should be enrolled in a surveillance program withannual colonoscopy with biopsies from the time of diagnosisof $\mathrm{PSC}^{159-}$ 161. This should be continued after liver transplantation in those with an intact colon given the increased CRC risk ${ }^{162}$. There is no role for prophylactic colectomy or increased intervals of surveillance in the transplantation setting ${ }^{158}$. There is currently no surveillance recommended for PSC patients with pouches. 


\section{CIRRHOTIC COMPLICATIONS}

PSC may follow a progressive course resulting in portal hypertension and liver failure. A median duration of 12 to 18 years from PSC diagnosis to the development of end-stage liver disease has been observed. Management of cirrhosis and its complications are the same as in other causes of chronic liver disease and has been discussed in detail in the recent European guidelines ${ }^{123}$.

\section{LIVER TRANSPLANT}

Liver transplantation is the treatment of choice in PSC patients with advanced endstage liver disease, and should be considered when the predicted life expectancy within one year is 85 to $90 \%$. Evaluation of patients with PSC for transplantation is inherently difficult due the unpredictability in disease course and the risk of biliary tract malignancy ${ }^{163}$. Prognostic models may help with timing decisions. The Model for End-Stage Liver Disease (MELD) score has become the primary tool to predict prognosis in and is an aetiology independent method to allocate organs in the United States ${ }^{164-165}$. Modified versions, including the United Kingdom End stage Liver Disease (UKELD) score, has been validated to allocate prioritisation for liver transplantation in the $\mathrm{UK}^{166}$. Indications are outlined in Table 6.

One year and 5 year survival rates for PSC have been reported to be as high as $97 \%$ and $88 \%$, respectively, from deceased donor allografts, comparing favourably to transplantation for other indications ${ }^{167-169}$. PSC can recur with a rate of 20 to $25 \%$ after 5 to 10 years of allograft transplantation, and at a higher rate after living donor transplant, if the graft is obtained from a biologically related donor ${ }^{170-172}$. The 
diagnosis of recurrence can be challenging, and is based upon consistent findings at liver biopsy and cholangiography, in the absence of other conditions that cause nonanastomotic stricturing ${ }^{173}$.The natural history of recurrent disease is variable; about one third with recurrence developing progressive disease over a 10-year follow up period leading to re-transplantation or death ${ }^{174}$. Re-transplantation rates seem higher for patients with PSC compared to other diseases ${ }^{175}$. Management after liver transplantation in patients with PSC is similar to other indications, except an increased risk of hepatic osteodystrophy and the role of IBD with increased risk of CRC requiring yearly colonoscopic surveillance.

\section{CONCLUSION}

PSC remains a challenging disease to manage. It is important firstly to differentiate PSC from variant forms, each requiring individualised management and follow-up. Despite considerable advancements, there is still no effective medical therapy that alters the natural history of disease. UDCA in high doses has recently yielded disappointing results, however there is a need to re-evaluate low to moderate dosesand to assess new therapies such as the novel bile acid 24-norursodeoxycholic acid to prevent disease progression and provide chemoprotection against biliary and colonic malignancy.Multi-centre randomised controlled trials are essential to evaluate survival, recruiting large number of patients for a long duration of time. Pilot studies are also important in carefully selected patients, given the relative rarity of disease, using more robust markers of efficacy such as serum markers of fibrosis and MRCP.

Dominant strictures are optimally managed with endoscopic dilatation and stenting to relieve biliary obstruction and its complications, after careful exclusion of a malignant 
1

4

5

6

7

8

9

10

11

12

13

14

15

16

17

18

19

20

21

22

23

24

25

26

27

28

29

30

31

32

33

34

35

36

37

38

39

40

41

42

43

44

45

46

47

48

49

50

51

52

53

54

55

56

57

58

59

60

stricture. Cholangiocarcinoma remains the most unpredictable and feared

complication of PSC, with no reliable screening test yet available, although the

outcome in highly selected groups undergoing chemoradiation and liver transplant is

promising. Transplantation remains the only option for patients with advanced

disease; timing remains problematic due to disease variation and recurrent disease.

Further work to understand the pathogenesis of disease, using genome studies, may

provide further targets for drug therapy and identify factors that lead to malignant

transformation, with the aim of halting its development. 


\title{
Declaration of Interests
}

There are no competing interests.

\author{
Financial Support \\ There was no financial support.
}

\section{References}

1. Chapman R\& $\underline{\text { Cullen } S}$. Etiopathogenesis of primary sclerosing cholangitis.World J Gastroenterol. 2008 Jun 7;14(21):3350-9.

2. Karlsen TH,$\underline{\text { Franke A, Melum E, et al.Genome-wide association analysis in }}$ primary sclerosing cholangitis.Gastroenterology. 2010 Mar;138(3):1102-11.

3. Broome U, Olsson R, Loof L, et al. Natural history and prognostic factors in 305Swedish patients with primary sclerosing cholangitis. Gut. 1996;38:610 15.

4. Abdalian R, Heathcote EJ. Sclerosing cholangitis:a focus on secondary causes. Hepatology 2006;44:1063-1074.

5. Boberg KM, Fausa O, Haaland T, et al. Features of autoimmune hepatitis in primarysclerosing cholangitis: an evaluation of 114 primary sclerosingcholangitispatients according to a scoring system for thediagnosis of autoimmune hepatitis.Hepatology1996;23:1369-1376.

6. Chapman RW, Cottone M, Selby WS, et al. Serum autoantibodies, ulcerative colitis and primary sclerosing cholangitis. Gut 1986;27:86-91.

7. Mulder AHL, Horst G, Haagsma EB, et al. Prevalence and characterization of neutrophil cytoplasmic antibodies in autoimmune liver diseases. Hepatology 1993;17:411-417. 
8. Vitellas KM, El-Dieb A, Vaswani KK, et al. MR cholangiopancreatography in patients with primary sclerosing cholangitis: interobserver variability and comparison with endoscopic retrograde cholangiopancreatography. AJR Am J Roentgenol 2002;179:399-407.

9. Dave M, Elmunzer BJ, Dwamena BA, et al. Primary Sclerosing Cholangitis: Meta-Analysis of Diagnostic Performance of MR Cholangiopancreatography Radiology. 2010 Aug; 256(2): 387-96.

10. Harrison RF, Hubscher SG. The spectrum of bile duct lesions in end-stage primary sclerosing cholangitis. Histopathology. 1991 Oct;19(4):321-7

11. Burak KW, Angulo P, Lindor KD. Is there a role for liver biopsy in primary sclerosing cholangitis? Am J Gastroenterol 2003;98:1155-1158.

12. Bjornsson E, Olsson R, Bergquist A, et al. The natural history of small-duct primary sclerosing cholangitis. Gastroenterology 2008;134:975-980.

13. Broome U, Glaumann H, Lindstom E, et al. Natural history and outcome in 32 Swedish patients withsmall duct primary sclerosing cholangitis (PSC). J Hepatol 2002;36:586-589.

14. Angulo P, Maor-Kendler Y, Lindor K, et al. Small-duct primary sclerosing cholangitis: A long term follow-up study. Hepatology 2002; 35: 1494-500.

15. Bjornsson E, Bomberg KM, Cullen S, et al. Patients with small duct primary sclerosing cholangitis have a favourable long term prognosis.Gut 2002; 51: $731-5$.

16. Gotthardt D, Runz H, Keitel V, et al. A mutation in the canalicular phospholipidtransporter gene, ABCB4, is associated with cholestasis, ductopenia, and cirrhosis in adults. Hepatology 2008;48:1157-1166. 
17. Charatcharoenwitthaya, P, Angulo, P, Enders, FB, Lindor, KD. Impact of inflammatory bowel disease and ursodeoxycholic acid therapy on small-duct primary sclerosing cholangitis. Hepatology 2008;47:133.

18. Gregorio GV, Portmann B, Karani J, et al. Autoimmune hepatitis/sclerosing cholangitis overlap syndrome in childhood: a 16-year prospective study. Hepatology 2001;33:544-553.

19. Al-Chalabi T, Portmann BC, Bernal W, et al. Autoimmune hepatitis overlap syndromes: an evaluationof treatment response, long-term outcome and survival. Aliment Pharmacol Ther 2008;28:209-220.

20. van Buuren HR, van Hoogstraten HJE, Terkivatan T, et al. High prevalence of autoimmune hepatitisamong patients with primary sclerosing cholangitis. J Hepatol2000;33:543-548.

21. Kaya M, Angulo P, Lindor KD. Overlap of autoimmunehepatitis and primary sclerosing cholangitis: an evaluation of a modified scoring system. J Hepatol 2000;33:537-542.

22. Floreani A, Rizzotto ER, Ferrara F, et al. Clinical course and outcome of autoimmunehepatitis/primary sclerosing cholangitis overlap syndrome. Am J Gastroenterol 2005;100:1516-1522

23. Lewin M, Vilgrain V, Ozeme V, et al. Prevalence of sclerosing cholangitis in adults with autoimmune hepatitis: A prospective magnetic resonance imaging and histological study. Hepatology 2009;50:528-537.

24. Abdalian R, Dhar P, Jhaveri, et al. Prevalence of sclerosing cholangitis in adults with autoimmune hepatitis: Evaluating the role of routine magnetic resonance imaging. Hepatology 2008;47:949-957. 
25. Abdo AA, Bain VG, Kichian K, et al. Evolution of autoimmunehepatitis to primary sclerosing cholangitis: a sequential syndrome. Hepatology 2002;36:1393-1399.

26. Boberg KM, Egeland T, Schrumpf E. Long-term effect of corticosteroidtreatment in primary sclerosing cholangitis patients.Scand J Gastroenterol 2003;38:991-995.

27. Bjornsson E, Chari ST, Smyrk TC, et al. Immunoglobulin G4 associatedcholangitis: description of an emerging clinical entity based on review of the literature. Hepatology 2007;45:1547-1554.

28. Ghazale A, Chari ST, Zhang L et al, Immunoglobulin-4 associated cholangitis: clinical profile and response to therapy. Gastroenterology, 2008;134:706-15.

29. Dastis SN, Latinne D, Sempoux C, et al. Ulcerative colitis associated with IgG4 cholangitis: similar features in two HLA identical siblings.J Hepatol. 2009 Sep;51(3):601-5.

30. Narula N, Vasudev M, Marshall JK.IgG(4)-Related Sclerosing Disease: A Novel Mimic of Inflammatory Bowel Disease.Dig Dis Sci.2010;55(11):30473051.

31. Mendes FD, Jorgensen R, Keach J, et al. Elevated serum IgG4 concentration in patients with primary sclerosingcholangitis. Am J Gastroenterol 2006;101:2070-2075.

32. Zhang L, Lewis JT, Abraham SC, et al. IgG4+ plasma cell infiltrates in liver explants with primary sclerosing cholangitis.Am J Surg Pathol. 2010 Jan;34(1):88-94 
33. Oh HC, Kim MH, Lee KT, et al. Clinical clues to suspicion of IgG4associated sclerosing cholangitis disguised as primary sclerosing cholangitis or hilar cholangiocarcinoma.J Gastroenterol Hepatol. 2010 Dec;25(12):1831-7

34. Chung H, Watanabe T, Kudo M, et al. Identification and characterization of IgG4-associated autoimmune hepatitis Liver Intern 2010;30(10)222-231.

35. Topazian M, Witzig TE, Smyrk TC, et al. Rituximab therapy for refractory biliary strictures in immunoglobulin G4 associated cholangitis. Clin Gastroenterol Hepatol 2008;6:364-6.

36. Kim WR, Therneau TM, Wiesner RH, et al. A revised natural history model for primary sclerosing cholangitis. Mayo Clin Proc 2000;75:688-94.

37. Kim WR, Poterucha JJ, Wiesner RH, et al. The relative role of the Child-Pugh classification and the Mayo natural history model in the assessment of survival in patients with primary sclerosing cholangitis.Hepatology 1999;29:16431648.

38. Bambha K, Kim WR, Talwalkar J, et al. Incidence, clinical spectrum, and outcomes of primary sclerosing cholangitis in a United States community. Gastroenterology 2003;125:1364-1369

39. Ponsioen CY, Vrouenraets SM, Prawirodirdjo W, et al. Natural history of primary sclerosing cholangitis and prognostic value of cholangiography in a Dutch population. Gut 2002;51:562-6.

40. Mendes FD, Kim WR, Pedersen R, et al. Mortality attributable to cholestatic liver disease in the United States. Hepatology 2008;47:1241-7.

41. Paumgartner G, Beuers U. Ursodeoxycholic acid in cholestatic liver diseases Hepatology 2002;36:525-531. 
42. Martinez JD, Stratagoules ED, La Rue JM, et al. Different bile acids exhibit distinct biological effects: the tumour promoter deoxycholic acid induces apoptosis and the chemopreventive agent ursodeoxycholic acid inhibits cell proliferation. Nutr Cancer 1998;31:111-118.

43. Beuers U, Spengler U, Kruis W, et al. Ursodeoxycholic acid for treatment of primary sclerosing cholangitis: a placebo-controlled trial. Hepatology 1992;16:707-714.

44. Chazouilleres O, Poupon R, Capron JP, et al. Ursodeoxycholic acid for primary sclerosing cholangitis. J Hepatol 1990;11:120-123

45. O’Brien CB, Senior JR, Arora-Mirchandani R, et al. Ursodeoxycholic acid for the treatment of primary sclerosing cholangitis: a 30-month pilot study. Hepatology 1991;14:838-847

46. Stiehl A. Ursodeoxycholic acid therapy in treatment of primary sclerosing cholangitis. Scand J Gastroenterol Suppl 1994;204:59-61.

47. Lindor KD. Ursodiol for primary sclerosing cholangitis. Mayo primary Sclerosing Cholangitis-Ursodeoxycholic Acid Study Group. N Engl J Med 1997;336:691-695

48. Lindor KD, Kowdley KV, Luketic VAC, et al. High dose ursodeoxycholic acid for the treatment of primary sclerosing cholangitis. Hepatology 2009;50(3):808-14.

49. Mitchell SA, Bansi DS, Hunt N, et al. A preliminary trial of high-dose ursodeoxycholicacid in primary sclerosing cholangitis.

Gastroenterology2001;121:900-907 
50. Olsson R, Boberg KM, de Muckadell OS, et al. High-dose ursodeoxycholic acid in primary sclerosingcholangitis: a 5-year multicentre, randomized, controlled study. Gastroenterology 2005;129:1464-1472

51. Cullen SN, Rust C, Fleming K, et al. High dose ursodeoxycholic acid for the treatment of primarysclerosing cholangitis is safe and effective. J Hepatol 2008;48:792-800.

52. Lindor KD, Enders FB, Schmoll JA, et al. Randomized, double-blind controlled trial of high-dose ursodeoxycholic acid for primary sclerosing cholangitis. Hepatology 2008;47:133-142.

53. Fickert P, Zollner G, Fuchsbichler A, et al. Ursodeoxycholic acid aggravates bile infarcts in bile duct-ligated and Mdr2 knockout mice via disruption of cholangioles. Gastroenterology2002;123:1238-1251.

54. Beneditti A, Alvaro D, Bassotti C, et al. Cytotoxicity of bile salts against biliary epithelium:a study in isolated bile ductile fragments and isolated perfused rat liver. Hepatology 1997;26:9-21.

55. Sinakos E, $\underline{\text { Marschall HU}}, \underline{\text { Kowdley KV}}$, et al. Bile acid changes after highdose ursodeoxycholic acid treatment in primary sclerosing cholangitis: Relation to disease progression.Hepatology, 2010;52(1):197-203.

56. Tung BY, Emond MJ, Haggitt RC, et al. Ursodiol use is associated with lower prevalence of colonicneoplasia in patients with ulcerative colitis and primary sclerosing cholangitis.Ann Intern Med 2001;134: 89-95.

57. Pardi DS, Loftus EV Jr, Kremers WK, et al. Ursodeoxycholicacid as a chemopreventive agent in patients with ulcerative colitisand primary sclerosing cholangitis. Gastroenterology 2003;124:889-893. 
58. Wolf JM, Rybicki LA, Lashner BA. The impact of ursodeoxycholic acid cancer, dysplasia and mortality in ulcerative colitis patients with primarysclerosing cholangitis. Aliment Pharmacol Ther 2005;22:783-788.

59. Rudolph G, Kloeters-Plachky P, Rost D, et al. The incidence of cholangiocarcinomain primary sclerosing cholangitis after long-time treatment with ursodeoxycholic acid. Eur J Gastroenterol Hepatol 2007;19:487-491.

60. Brandsaeter B, Isoniemi $\mathrm{H}$, Broome' $\mathrm{U}$, et al. Liver transplantation for primary sclerosing cholangitis; predictors and consequences of hepatobiliary malignancy. J Hepatol 2004;40:815-822.

61. Halilbasic E, Fiorotto R, Fickert P, et al. Sidechain structure determines unique physiologic and therapeutic properties of norursodeoxycholic acid in Mdr-/- mice. Hepatology 2009;49:1972-82.

62. Glaser SS, Alpini G, Hightower NC. Activation of the cholehepatic shuntas a potential therapy for primary sclerosing cholangitis. Hepatology 2009;49:1790-2.

63. Cullen SN, Chapman RW. Review article: current management of primary sclerosing cholangitis. Aliment Pharmacol Ther 2005;21:933-948.

64. Chapman R, Fevery J, Kalloo A, et al. AASLD Practice Guidelines: Diagnosis and management of primary sclerosing cholangitis. Hepatology 2010;51(2):660-78

65. Bjornsson E, Lindqvist-Ottosson J, Asztely M, et al. Dominantstrictures in patients with primary sclerosing cholangitis.Am J Gastroenterol2004;99:502508.

66. Stiehl A, Rudolph G, Kloters-Plachky P, et al. Developmentof dominant bile duct stenoses in patients with primary sclerosingcholangitis treated with 
ursodeoxycholic acid: outcome after endoscopictreatment. J Hepatol 2002;36:151-156.

67. Rudolph G, Gotthardt D, Klöters-Plachky P, et al. Influence of dominant bile duct stenoses and biliary infections on outcome in primary sclerosing cholangitis. J Hepatol 2009;51(1):149-55.

68. Lindberg B, Arnelo U, Bergquist A, et al. Diagnosis of biliary strictures in conjunction with endoscopic retrograde cholangiopancreaticography, with special reference to patients with primary sclerosing cholangitis. Endoscopy 2002;34:909-916.

69. Gaing AA, Geders JM, Cohen SA, et al. Endoscopic management ofprimary sclerosing cholangitis: review, and report of an open series. AmJ Gastroenterol 1993;88:2000-08.

70. Johnson GK, Geenen JE, Venu RP, et al. Endoscopictreatment of biliary tract strictures in sclerosing cholangitis: a larger series and recommendations for treatment. Gastrointest Endosc 1991;37:38-43.

71. Kaya M, Petersen BT, Angulo P, et al. Balloon dilation compared to stenting of dominant strictures in primary sclerosing cholangitis. Am J Gastroenterol 2001;96:1059-1066.

72. Gaing AA, Geders JM, Cohen SA, et al. Endoscopic therapy forprimary sclerosing cholangitis: Report of an ongoing series. GastrointestEndosc $1992 ; 38: 261-262$

73. Baluyut AR, Sherman S, Lehman GA, et al. Impact of endoscopic therapy on the survival of patients withprimary sclerosingcholangitis. Gastrointest Endosc2001;53:308-312. 
74. Stiehl A, Rudolph G, Sauer P,et al. Efficacy of ursodeoxycholic acid treatment and endoscopic dilation of major duct stenoses in primary sclerosing cholangitis:an 8-year prospective study. J Hepatol 1997;26:560-566.

75. Johnson GK, Geenen JE, Venu RP, et al. Endoscopic treatment of biliary tract strictures in sclerosingcholangitis: a larger series and recommendations for treatment.Gastrointest Endosc 1991;37:38-43.

76. van Milligen de Wit AW, van Bracht J, Rauws EA, et al. Endoscopic stent therapy for dominant extrahepatic bile duct strictures in primary sclersosing cholangitis. Gastrointest Endosc 1996;44:293-299.

77. Bangarulingam SY, Gossard AA, Petersen BT, et al. Complications of endoscopic retrograde cholangiopancreatography in primary sclerosing cholangitis. Am J Gastroenterol. 2009 Apr;104(4):855-60.

78. Eickhoff A et al, Long-term outcome of percutaneous transhepatic drainage forbenign bile duct stenoses. Rocz Akad Med Bialymst. 2005;50:155-60.

79. Ahrendt SA, Pitt HA, Kalloo AN, et al. Primary sclerosing cholangitis: resect, dilate, or transplant?Ann Surg1998;227:412-423.

80. Angulo P, Lindor KD. Primary sclerosing cholangitis. Hepatology $1999 ; 30: 325-32$.

81. Farges O, Malassagne B, Sebagh M, et al. Primary sclerosing cholangitis: liver transplantation or biliary surgery. Surgery, 1995;117:146-55.

82. Muiesan P, Shanmugam RP, Delvin J, et al. Orthotopic liver transplantation for primary sclerosing cholangitis. Transplant Proc, 1994;26:3574-76.

83. Narumi S, Roberts JP, Emond JC, et al. Liver transplant for sclerosing cholangitis. Hepatology 1995;22:451-57. 
84. Tsai S, Pawlik TM. Primary sclerosing cholangitis: the role of extrahepatic biliary resection. Adv Surg. 2009;43:175-88.

85. Pawlick TM, Olbrecht VA, Pitt HA, et al. Primary sclerosing cholangitis: role of extrahepatic biliary resection. J Am Coll Surg 2008;206:822-830.

86. Cameron JL, Pitt HA, Zinner MJ, et al. Resection of hepatic duct bifurcation and transhepatic stenting for sclerosing cholangitis. Ann Surg 1988;207:614622.

87. Myburgh JA. Surgical biliary drainage in primary sclerosing cholangitis. The role of the Hepp-Couinaud approach. Arch Surg 1994;129:1057-1062.

88. Kaplan GG, Laupland KB, Butzner D, et al. The burden of large and small duct primary sclerosing cholangitis in adults and children: a population-based analysis. Am J Gastroenterol 2007;102:1042-1049.

89. Pohl J, Ring A, Stremmel W, Stiehl A. The role of dominant stenoses in bacterial infections of bile ducts in primary sclerosing cholangitis. Eur $\mathbf{J}$ Gastroenterol Hepatol 2006;18:69-74.

90. Negm AA, Schott A, Vonberg RP, et al. Routine bile collection for microbiological analysis during cholangiography and its impact on the management of cholangitis. Gastrointest Endosc. 2010;72(2):284-291.

91. Abraham SC, Kamath PS, Eghtesad B, et al. Liver transplantation in precirrhotic biliary tract disease: Portal hypertension is frequently associated with nodular regenerative hyperplasia and obliterative portal venopathy. Am J Surg Pathol 2006;30:1454-1461.

92. Bergquist A, Ekbom A, Olsson R, Hepatic and extrahepatic malignancies in primary sclerosing cholangitis.J Hepatol. 2002 Mar;36(3):321-7. 
93. Maggs JR, Chapman RW. An update on primary sclerosing cholangitis. Curr Opin Gastroenterol 2008;24:377-383.

94. Burak K, Angulo P, Pasha TM, et a. Incidence and risk factors for cholangiocarcinoma in primary sclerosing cholangitis. Am J Gastroenterol, 2004;99:523-26.

95. Boberg KM, Bergquist A, Mitchell S, et al. Cholangiocarcinoma in primary sclerosing cholangitis: risk factors and clinical presentation. Scand J Gastroenterol, 2002;37:1205-11.

96. Kornfeld D, Ekbom A, Ihre T. Survival and risk of cholangiocarcinoma in patients with primary sclersosing cholangitis. A population based study. Scand J Gastroenterol 1997;32:1042-5.

97. Helzberg JH, Petersen JM, Boyer JL. Improved survival with primary sclersosing cholangitis. A review of clinicopathologic features and comparison of symptomatic and asymptomatic patients. Gastroenterol 1987;92:1869-75.

98. Lazaridis KN, Gores GJ. Primary sclerosing cholangitis and cholangiocarcinoma.Semin Liver Dis 2006;26:42-51.

99. Yachimski P, Pratt DS. Cholangiocarcinoma: Natural history, treatment and strategies for surveillance in high risk patients. J Clin Gastroenterol 2008;42:178-90.

100. Charatcharoenwitthaya P, Enders FB, Halling KC, et al. Utility of serum tumor markers, imaging, and biliary cytologyfor detecting cholangiocarcinoma in primary sclerosing cholangitis. Hepatology 2008;48:1106-1117. 
101. Angulo P, Pearce DH, Johnson CD, et al. Magnetic resonance cholangiography in patients with biliary disease: its role in primary sclerosing cholangitis. J Hepatol 2000;33:520-7.

102. Rabinovitz M, Zajko AM, Hassanein T et al. Diagnostic value of brush cytology in the diagnosis of bile duct carcinoma: A study of 65 patients with bile duct strictures. Hepatology 1990;12:747-52.

103. Boberg KM, Jebsen P, Clausen OP, et al. Diagnostic benefit of biliary brush cytology in cholangiocarcinoma in primary sclerosing cholangitis. $\mathrm{J}$ Hepatol. 2006;45:568-74.

104. Moreno Luna LE, Kipp B, Halling KC, et al. Advanced cytological techniques for the detection of malignant pancreatobiliary strictures. Gastroenterology 2006;131:1064-72.

105. Kipp BR, Stadheim LM, Halling SA, et al. A comparison of routine cytology and fluorescence in situ hybridisation for the detection of malignant bile duct strictures. Am J Gastroenterol, 2004;99:1675-81.

106. Levy C, Lymp J, Angulo P, et al. The valueof serum CA 19-9 in predicting cholangiocarcinomas in patients with primary sclerosing cholangitis. Dig Dis Sci 2005;50:1734-40.

107. Steinberg W. The clinical utility of the CA 19-9 tumor-associated antigen. Am J Gastroenterol 1990;85:350-355.

108. Fritscher-Ravens A, Broering DC, Knoefel WT, et al. EUS-guided fine-needle aspiration of suspected hilarcholangiocarcinoma in potentially operable patients with negative brushcytology. Am J Gastroenterol 2004;99:45-51. 
109. Gleeson FC, Rajan E, Levy MJ, et al. EUS-guided FNA of regional lymph nodes in patients with unresectable hilar cholangiocarcinoma. Gastrointest Endosc 2008;67:438-443.

110. Fevery J, Verslype C, Lai G, et al. Incidence, diagnosis and therapy of cholangiocarcinoma in patients with primary sclerosing cholangitis. Dig Dis Sci, 2007;52:3123-35

111. Meza-Junco J, Montano-Loza AJ, Ma M, et al. Cholangiocarcinoma: has there been any progress. Can J Gastroenterol. 2010 Jan;24(1):52-7.

112. IIwatsuki S, Todo S, Marsh JW, et al. Treatment of hilar cholangiocarcinoma (Klatskin tumours) with hepatic resection or transplantation. J Am Coll Surg 1998;187:358-64.

113. Rea DJ, Heimbach JK, Rosen CB, et al. Liver transplantation with neoadjuvant chemoradiation ismore effective than resection for hilar cholangiocarcinoma. Ann Surg2005;242:451-458; discussion 458-461.

114. Hemibach JK, Gores GJ, Nagorney DM, et al. Liver transplantation for perihilar cholangiocarcinoma after aggressive neoadjuvant therapy: a new paradigm for liver and biliary malignancies? Surgery 2006;140:331-4.

115. Gores GJ, Nagorney DM, Rosen CB.Cholangiocarcinoma: is transplantationan option? For whom? J Hepatol 2007;47:455-459.

116. Sudan D, DeRoover A, Chinnakotla S, et al. Radiochemotherapy and transplantation allow long-term survival for non-resectable hilar cholangiocarcinoma. Am J Transplant 2002;2:774-9.

117. Kahaleh M, Mishra R, Shami VM, et al. Unresectable cholangiocarcinoma: comparison of survival in biliarystenting alone versus 
stenting with photodynamic therapy. Clin Gastroenterol Hepatol 2008;6:290297.

118. Brandt DJ, MacCarty RL, Charboneau JW, et al. Gallbladder disease in patients with primary sclerosing cholangitis.Am J Roentgenol1988;150:571574.

119. Said K, Glaumann H, Bergquist A. Gallbladder disease in patients with primary sclerosing cholangitis. J Hepatol2008;48:598-605.

120. Buckles DC, Lindor KD, Larusso NF, et al. In primarysclerosing cholangitis, gallbladder polyps are frequently malignant. Am J Gastroenterol 2002;97:1138-1142.

121. Lewis JT, Talwalker JA, Rosen CB, et al. prevalence and risk factors for gallbladder neoplasia in patients with primary sclerosing cholangitis: evidence for metaplasia-dysplasia-carcinoma sequence. Am J Surg Pathol, 2007;31:907-13.

122. Leung UC, Wong PY, Roberts RH, et al. Gallbladder polyps in sclerosing cholangitis: does the 1cm rule apply? ANZ J Surg 2007;77:355-57.

123. Beuers U, Boberg K, Chapman RW, et al. EASL Clinical Practice Guidelines: management of cholestatic liver diseases. J Hepatol 2009;51:23767.

124. Harnois DM, Gores GJ, Ludwig J, et al. Are patients with cirrhotic stage primary sclerosingcholangitis at risk for the development of hepatocellular cancer?J Hepatol 1997;27:512-516.

125. Bruix J \& Sherman M. ASSLD Practice Guidelines: Management of Hepatocellular Carcinoma. Hepatology, 2005;42(5):1208-35. Updated Hepatology, 2010;1-35. 
126. Jones EA, Bergasa NV. The pruritis of cholestasis. Hepatology 1999;29:1003-6

127. Datta DV, Sherlock S. Cholestyramine for long term relief of pruritus complicating intrahepatic cholestasis. Gastroenterology.1966;50:323-332.

128. Polter DE, Gruhl V, Eigenbrodt EH, et al. Beneficial effects of cholestyramine in sclersosing cholangitis. Gastroenterology 1980;79:326-33.

129. Khurana S, Singh P. Rifampin is safe for the treatment of pruritus due to chronic cholestasis: a meta-analysis of prospective randomized-controlled trials. Liver Int 2006;26:943-948.

130. Tandon P, Rowe BH, Vandermeer B, et al. The efficacy and safety of bile acid binding agents, opioid antagonists or rifampicin in the treatment of cholestasis-associated pruritus Am J Gastroenterol 2007;102:1528-1536.

131. Wolfhagen FH, Sternieri E, Hop WC, et al. Oral naltrexone treatment for cholestatic pruritus: a double-blind, placebo-controlled study. Gastroenterology 1997;113:1264-1269.

132. Bergasa NV, Alling DW, Talbot TL, et al. Effects of naloxone infusions in patients with the pruritus of cholestasis. A double-blind, randomized, controlled trial. Ann Intern Med 1995;123:161-67.

133. Jones EA, Molenaar HA, Oosting J. Ondansetron and pruritus in chronic liver disease: a controlled study. Hepatogastroenterology 2007;54:1196-1199.

134. Mayo MJ, Handem I, Saldana S, Jacobe H, Getachew Y, Rush AJ. Sertraline as a first-line treatment for cholestatic pruritus. Hepatology 2007;45:666-74. 
135. Epstein MP, Kaplan MM. A pilot study of etanercept in the treatment of primary sclerosing cholangitis. Dig Dis Sci 2004;49:1-4.

136. Jones DE, Newton JL. An open study of modafinil for the treatment of daytime solomnence and fatigue in primary biliary cirrhosis. Aliment Pharmocol Ther 2007;25:471-76.

137. Angulo P, Therneau TM, Jorgensen A, et al. Bone disease in patients with primary sclerosing cholangitis: prevalence, severity and prediction of progression. J Hepatol 1998;29:729-735.

138. Porayko MK, Wiesner RH, Hay JE, et al. Bone disease in liver transplant recipients: incidence, timing, and risk factors. Transplant Proc $1991 ; 23: 1462-1465$.

139. Pares A, Guanabens N. Osteoporosis in primary biliary cirrhosis: pathogenesis and treatment. Clin Liver Dis 2008;12:407-24.

140. Pereira SP, O’Donohue J, Moniz C, et al. Transdermal hormone replacement therapy imporves vertebral bone density in primary biliary cirrhosis: results of a one year controlled trial. Aliment Pharmacol Therap 2007;25:471-76.

141. Wiesner RH, Grambsch PM, Dickson ER, et al. Primary sclerosing cholangitis: natural history, prognosticfactors and survival analysis. Hepatology 1989;10:430-436.

142. Chapman RW, Arborgh BA, Rhodes JM, et al. Primary sclerosing cholangitis: a review ofits clinical features, cholangiography, and hepatic histology. Gut 1980;21:870-877. 
143. Fausa O, Schrumpf E, Elgjo K. Relationship of inflammatory boweldisease and primary sclerosing cholangitis. Semin Liver Dis 1991;11:3139.

144. Verdonk RC, Dijkstra G, Haagsma EB, et al. Inflammatory bowel disease after liver transplantation: risk factors for recurrence and de novo disease. Am J Transplant2006;6:1422-1429.

145. Loftus Jr EV, Harewood GC, Loftus CG, et al. PSC-IBD: a unique formof inflammatory bowel disease associated with primary sclerosing cholangitis. Gut 2005;54:91-96.

146. Broome U, Bergquist A. Primary sclerosing cholangitis, inflammatory bowel disease, and colon cancer. Semin Liver Dis 2006;26:31-41.

147. Lundqvist K, Broome U. Differences in colonic disease activity in patients with ulcerative colitis with and without primary sclerosing cholangitis: a case control study. Dis Colon Rectum 1997;40:451-456.

148. Penna C, Dozois R, Tremaine W, et al. Pouchitis after ileal pouch-anal anastomosis for ulcerative colitisoccurs with increased frequency in patients with associated primary sclerosing cholangitis. Gut 1996;38:234-239.

149. Wiesner RH, LaRusso NF, Dozois RR, et al. Peristomal varices after proctocolectomy in patients with primary sclerosing cholangitis.

Gastroenterology 1986;90:316-322.

150. Schrumpf E, Elgjo K, Fausa O, et al. Sclerosing cholangitis in ulcerative colitis. Scand J Gastroenterol 1980;15:689-697.

151. Olsson R, Danielsson A, Jarnerot G, et al. Prevalence of primsary sclerosing cholangitis in ulcerative colitis. Gastroenterology 1991;100:131923 
152. Rabinovitz M, Gavaler JS, Schade RR, et al. Does primary sclerosing cholangitis occurring in association with inflammatory bowel disease differ from that occurring in the absence of inflammatory bowel disease? A study of sixty-six subjects. Hepatology 1990;11(1):7-11.

153. Soetikno RM, Lin OS, Heidenreich PA, et al. Increased risk of colorectal neoplasia in patients with primary sclerosingcholangitis and ulcerative colitis: a meta-analysis. Gastrointest Endosc2002;56:48-54.

154. Broome, U, Lofberg, R, Veress, B, Eriksson, LS. Primary sclerosing cholangitis and ulcerative colitis: Evidence for increased neoplastic potential. Hepatology $1995 ; 22: 1404$.

155. Naggengast F, Grubben M, van Munster I. Role of bile acids in colorectal carcinogenesis. Eur J Cancer. 1995;31:1067-1070.

156. Shetty K, Rybicki L, Brzezinski A, et al. The risk forcancer or dysplasia in ulcerative colitis patients with primary sclerosingcholangitis. Am J Gastroenterol 1999;94:1643-1649.

157. Marchesa, P, Lashner, BA, Lavery, IC, et al. The risk of cancer and dysplasia among ulcerative colitis patients with primary sclerosing cholangitis. Am J Gastroenterol 1997; 92:1285.

158. Loftus Jr EV, Aguilar HI, Sandborn W, et al. Risk of colorectal neoplasia in patients with primary sclerosing cholangitis and ulcerative colitis following orthotopicliver transplantation. Hepatology 1998;27(3):685-90.

159. Cairns S, Scholefield JH, Steele RJ, et al. Guidelines for colorectal cancer screening and surveillance in moderate and high risk groups. Gut 2010;59:666-689. 
160. Kaplan GG, Heitman SJ, Hilsden RJ, et al. Population-based analysis of practices and costs of surveillance forcolonic dysplasia in patients with primary sclerosing cholangitis and colitis. Inflamm Bowel Dis 2007;13:14011407.

161. Kitiyakara T, Chapman RW. Chemoprevention and screening in primary sclerosing cholangitis. Postgrad Med J 2008;84:228-37.

162. MacLean AR. Outcome of Patients Undergoing Liver Transplantation for Primary Sclerosing Cholangitis. Dis Colon Rectum 2003;46(8):1124-28.

163. Bjøro K, Brandsaeter B, Foss A,Schrumpf E. Liver transplantation in primary sclerosing cholangitis. SeminLiver Dis. 2006 Feb;26(1):69-79.

164. Wiesner RH, McDiarmid SV, Kamath PS, et al. MELD and PELD: application of survival models toliver allocation. Liver Transpl 2001;7:567580.

165. Freeman RB, Edwards EB, Harper AM. Waiting list removal rates amongpatients with chronic and malignant liver diseases.AmJ Transplant 2006;6:1416-1421.

166. Neuberger J, Gimson A, Davies M, et al. Selection of patients for liver transplantation and allocation of donated livers in the UK.Gut2008;57:252257.

167. Brandsaeter B, Friman S, Broome U, et al. Outcome following liver transplantation for primary sclerosingcholangitis in the Nordic countries. Scand J Gastroenterol 2003;38:1176-1183.

168. Graziadei IW, Wiesner RH, Marotta PJ, et al. Long-term results of patients undergoing liver transplantationfor primary sclerosing cholangitis. Hepatology 1999;30:1121-1127. 
169. Roberts MS, Angus DC, Bryce CL, et al. Survival after liver transplantation in the United states : A disease specific analysis of the UNOS database. Liver Transpl 2004;10:886-97.

170. Campsen J, Zimmerman MA, Trotter JF, et al. Clinically recurrent primary sclerosing cholangitis following livertransplantation: a time course. Liver Transpl 2008;14:181-185.

171. Graziadei IW, Wiesner RH, Batts KP, et al. Recurrence of primary sclerosing cholangitis following liver transplantation. Hepatology 1999;29:1050-6.

172. Tamura S, Sugawara Y, Kaneko J, et al. Recurrence of primary sclerosing cholangitis after living donor transplantation. Liver Int 2007;27:8694.

173. Wojcicki M, Milkiewicz P, Silva M. Biliary tract complications after livertransplantation: a review. Dig Surg 2008;25:245-257.

174. Alabraba E, Nightingale P, Gunson B, at el. A re-evaluation of the risk factors for the recurrence of primary sclerosing cholangitis in liver allografts. Liver Transplant 2009;15(3):330-40.

175. La Russo NF, Shneider BL, Black D, et al. Primary sclerosing cholangitis: summary of a workshop. Hepatology 2006;44:746-64.

176. Lo SK, Hermann R, Chapman RW, et al. Ursodeoxycholic acid in primary sclerosing cholangitis.: a double blind placebo controlled trial. Hepatology 1992;16:92A.

177. Stiehl A, Walker S, Stiehl L, Rudolph G, Hofmann WJ, Theilmann L. Effect of ursodeoxycholic acid on liver and bile duct disease in primary 
sclerosing cholangitis. A 3-year pilot study with a placebo-controlled study period. J Hepatol 1994;20:57-64.

178. De Maria N, Colantoni A, Rosenbloom E, et al. Ursodeoxycholic acid does not improve the clinical course of primary sclerosing cholangitis over a 2 year period. 1996;43:1472-9.

179. Van Hoogstraten HJ, Wolfhagen FH, van de Meeberg PC, et al. Ursodeoxycholic acid therapy for primary sclersosing cholangitis: results of a 2year randomised controlled trial to evaluate single vs. multiple daily disease. J Hepatol 1998;29:417-23.

180. Harnois DM, Angulo P, Jorgensen RA, LaRusso NF, Lindor KD. Highdose ursodeoxycholic acid as a therapy for patients with primary sclerosing cholangitis. Am J Gastroenterol 2001:96:1558-1562.

181. Okolicsanyi L, Groppo M, Floreani A, Morselli-Labate AM, Rusticali AG, Battocchia A, et al. Treatment of primary sclerosing cholangitis with lowdose ursodeoxycholic acid: results of a retrospective Italian multicentresurvey. Dig Liver Dis 2003;35:325-331.

182. Angulo P, Batts KP, Jorgensen RA, et al. Oral budesonide in the treatment of primary sclerosing cholangitis.Am J Gastroenterol 2000;95:23337.

183. Knox, TA, Kaplan, MM. Treatment of primary sclerosing cholangitis with oral methotrexate. Am J Gastroenterol 1991;86:546.

184. Knox TA, Kaplan MM. A double-blind controlled trial of oral-pulse methotrexate therapy in the treatment of primarysclerosing cholangitis. Gastroenterology 1994;106:494-9. 
185. Sandborn WJ, Wiesner RH, Tremaine WJ, et al. Ulcerative colitis disease activity following treatment of associated primary sclerosing cholangitis with cyclosporin. Gut 1993;34:242-6.

186. Van Thiel DH, Carroll P, Abu-Elmagd K, et al. Tacrolimus (FK506), a treatment for primary sclerosing cholangitis: Results of an open-label preliminary trial. Am J Gastroenterol 1995;90:455-9.

187. Olsson R, Broome U, Danielsson A, et al. Colchicine treatment of primary sclerosing cholangitis. Gastroenterology 1995;108:1199-203.

188. LaRusso NF, Wiesner RH, Ludwig J, et al. Prospective trial of penicillamine in primary sclerosing cholangitis. Gastroenterology 1988;95:1036-42.

189. Bharucha AE, Jorgensen R, Lichtman SN, et al. A pilot study of pentoxifylline for the treatment of primarysclerosing cholangitis. Am J Gastroenterol 2000;95:2338-42.

190. Duchini A, Younossi ZM, Saven A, et al. An open-label pilot trial of cladibrine (2-cholordeoxyadenosine) in patients with primary sclerosing cholangitis. J Clin Gastroenterol 2000;31:292-6.

191. Angulo P, MacCarty RL, Sylvestre PB, et al. Pirfenidone in the treatment of primary sclerosing cholangitis. Dig Dis Sci 2002;47:157-61.

192. Angulo P, Bharucha AE, Jorgensen RA, et al. Oral nicotine in treatment of primary sclerosing cholangitis: A pilot study. Dig Dis Sci 1999;44:602-7.

193. Vleggaar FP, van Buuren HR, van Berge Henegouwen GP, et al. No beneficial effects of transdermal nicotinein patients with primary sclerosing 
cholangitis: Results of a randomized double-blind placebo-controlled crossover study. Eur J Gastroenterol Hepatol 2001;13:171-5.

194. Epstein MP, Kaplan MM. A pilot study of etanercept in the treatment of primary sclerosing cholangitis. Dig Dis Sci2004;49:1-4.

195. Talwalkar JA, Angulo P, Keach JC, et al. Lindor KD. Mycophenolate mofetil for the treatment of primarysclerosing cholangitis. Am J Gastroenterol 2005;100:308-12.

196. Talwalkar JA, Gossard AA, Keach JC, et al. Tacrolimus for the treatment of primary sclerosing cholangitis. Liver Int 2007;27:451-3.

197. Hommes DW, Erkelens W, Ponsioen C, et al. A double-blind, placebocontrolled, randomized study of infliximab in primary sclerosing cholangitis. J Clin Gastroenterol 2008;42:522-6.

198. Angulo P, Jorgensen RA, Kowdley KV, Lindor KD. Silmarin in the treatment of patients with primary sclerosing cholangitis: an open label pilot study. Dig Dis Sci 2008 Jun;53(6):1716-20.

199. Mizuno S, Hirano K, Tada M, et al. Bezafibrate for the treatment of primary sclerosing cholangitis. J Gastroenterol 2010 Feb (online).

200. Lindor, KD, Wiesner, RH, Colwell, L, et al. The combination of prednisone and colchicine in patients with primary sclerosing cholangitis. Am J Gastroenterol 1991;86:57.

201. Kyokane, K, Ichihara, T, Horisawa, M, et al. Successful treatment of primary sclerosing cholangitis with cyclosporine and corticosteroid. Hepatogastroenterology 1994;41:449. 
202. Lindor, KD, Jorgensen, RA, Anderson, ML, et al. Ursodeoxycholic $\underline{\text { acid and methotrexate for primary sclerosing cholangitis: A pilot study. Am J }}$ Gastroenterol 1996;91:511.

203. Schramm, C, Schirmacher, P, Helmreich-Becker, I, et al. Combined therapy with azathioprine, prednisolone, and ursodiol in patients with primary sclerosing cholangitis. Ann Intern Med 1999;131:943.

204. van Hoogstraten, HJ, Vleggaar, FP, Boland, GJ, et al. Budesonide or prednisone in combination with ursodeoxycholic acid in primary sclerosing cholangitis: a randomized double-blind pilot study. Belgian-Dutch PSC Study Group. Am J Gastroenterol 2000;95:2015.

205. Sterling RK, Salvatori JJ, Luketic VA, et al. A prospective, randomized-controlled pilot study of ursodeoxycholic acidcombined with mycophenolate mofetil in the treatment of primary sclerosing cholangitis. Aliment Pharmacol Ther 2004;20:943-9.

206. Davies, YK, Cox, KM, Abdullah, BA, et al. Long-term treatment of primary sclerosing cholangitis in children with oral vancomycin: an immunomodulating antibiotic. J Pediatr Gastroenterol Nutr 2008;47:61.

207. Silveira, MG, Torok, NJ, Gossard, AA, et al. Minocycline in the $\underline{\text { treatment of patients with primary sclerosing cholangitis: results of a pilot }}$ study. Am J Gastroenterol 2009;104:83.

208. Farkkila, M, Karvonen, AL, Nurmi, H, et al. Metronidazole and $\underline{\text { ursodeoxycholic acid for primary sclerosing cholangitis: a randomized }}$ placebo-controlled trial. Hepatology 2004;40:1379. 
Table1: Trials of UDCA in PSC

\begin{tabular}{|c|c|c|c|c|c|}
\hline Reference & Type of study & $\begin{array}{l}\text { No. of } \\
\text { patients }\end{array}$ & Dose of UDCA & $\begin{array}{l}\text { Duration } \\
\text { (months) }\end{array}$ & Outcomes \\
\hline $\begin{array}{l}\text { Chazouillères } \\
\text { et al, } 1990 \\
{[44]}\end{array}$ & Prospective & 15 & $750-1250 \mathrm{mg}$ & 6 & $\begin{array}{l}\text { Improved liver function and } \\
\text { symptoms. }\end{array}$ \\
\hline $\begin{array}{l}\text { O'Brien et al, } \\
1991 \\
{[45]}\end{array}$ & Open-label & 12 & $10 \mathrm{mg} / \mathrm{kg}$ & 30 & $\begin{array}{l}\text { Improved liver function and } \\
\text { symptoms. }\end{array}$ \\
\hline $\begin{array}{l}\text { Beuers et al, } \\
1992[43]\end{array}$ & $\begin{array}{l}\text { Double-blind, } \\
\text { placebo- } \\
\text { controlled }\end{array}$ & 6 & $13-15 \mathrm{mg} / \mathrm{kg}$ & 12 & $\begin{array}{l}\text { Improved liver function and histology. } \\
\text { No effect on symptoms. }\end{array}$ \\
\hline $\begin{array}{l}\text { Lo et al, } 1992 \\
{[176]}\end{array}$ & $\begin{array}{l}\text { Double-blind } \\
\text { placebo } \\
\text { controlled }\end{array}$ & 23 & $10 \mathrm{mg} / \mathrm{kg}$ & 24 & $\begin{array}{l}\text { Improved liver function. } \\
\text { No effect on symptoms or histology }\end{array}$ \\
\hline $\begin{array}{l}\text { Stiehl et al, } \\
1994 \text { [177] }\end{array}$ & $\begin{array}{l}\text { Double-blind, } \\
\text { placebo- } \\
\text { controlled }\end{array}$ & 20 & $750 \mathrm{mg}$ & $12-48$ & $\begin{array}{l}\text { Improved liver function and histology. } \\
\text { No effect on symptoms. }\end{array}$ \\
\hline $\begin{array}{l}\text { De Maria et } \\
\text { al, } 1996[178]\end{array}$ & $\begin{array}{l}\text { Double-blind } \\
\text { placebo } \\
\text { controlled } \\
\end{array}$ & 59 & $600 \mathrm{mg}$ & 24 & No improvement in liver function. \\
\hline $\begin{array}{l}\text { Lindor et al, } \\
1997[47]\end{array}$ & $\begin{array}{l}\text { Double-blind, } \\
\text { placebo- } \\
\text { controlled }\end{array}$ & 105 & $13-15 \mathrm{mg} / \mathrm{kg}$ & 34 & $\begin{array}{l}\text { Improved liver function. } \\
\text { No effect on histology and symptoms. }\end{array}$ \\
\hline $\begin{array}{l}\text { Van } \\
\text { Hoogstraten } \\
\text { et al, } 1998 \\
{[179]}\end{array}$ & Double-blind & 48 & $10 \mathrm{mg} / \mathrm{kg}$ & 24 & $\begin{array}{l}\text { Improved liver function. } \\
\text { No effect on symptoms. }\end{array}$ \\
\hline $\begin{array}{l}\text { Mitchell et al, } \\
2001[49]\end{array}$ & $\begin{array}{l}\text { Double-blind, } \\
\text { placebo- } \\
\text { controlled }\end{array}$ & 26 & $20-25 \mathrm{mg} / \mathrm{kg}$ & 24 & $\begin{array}{l}\text { Improved liver function, histology and } \\
\text { cholangiography. } \\
\text { No effect on symptoms. } \\
\text { No survival benefit. }\end{array}$ \\
\hline $\begin{array}{l}\text { Harnois et al, } \\
2001[180]\end{array}$ & Open label & 30 & $25-30 \mathrm{mg} / \mathrm{kg}$ & 12 & $\begin{array}{l}\text { Improved liver function and survival } \\
\text { compared with Mayo risk score. }\end{array}$ \\
\hline $\begin{array}{l}\text { Okolicsanyi et } \\
\text { al, } 2003 \text { [181] }\end{array}$ & $\begin{array}{l}\text { Open-label, } \\
\text { placebo- } \\
\text { controlled }\end{array}$ & 86 & $8-13 \mathrm{mg} / \mathrm{kg}$ & 120 & $\begin{array}{l}\text { Improved liver function and symptoms. } \\
\text { No effect on histology. }\end{array}$ \\
\hline $\begin{array}{l}\text { Olsson et al, } \\
2005[50]\end{array}$ & $\begin{array}{l}\text { multi-centre } \\
\text { randomised } \\
\text { Double-blind, } \\
\text { placebo- } \\
\text { controlled }\end{array}$ & 219 & $17-23 \mathrm{mg} / \mathrm{kg}$ & 60 & $\begin{array}{l}\text { Improved liver function. } \\
\text { Non-significant trend towards increased } \\
\text { survival. No effect on symptoms. }\end{array}$ \\
\hline $\begin{array}{l}\text { Cullen et al, } \\
2008[51]\end{array}$ & $\begin{array}{l}\text { Pilot dose range } \\
\text { study }\end{array}$ & 30 & $\begin{array}{l}10 \mathrm{mg} / \mathrm{kg} \\
20 \mathrm{mg} / \mathrm{kg} \\
30 \mathrm{mg} / \mathrm{kg} /\end{array}$ & 24 & $\begin{array}{l}\text { Improved projected survival with low } \\
\text { and standard dose. Significantly } \\
\text { improved projected survival with high } \\
\text { dose. }\end{array}$ \\
\hline $\begin{array}{l}\text { Lindor et al, } \\
2009[48]\end{array}$ & $\begin{array}{l}\text { multi-centre } \\
\text { Double-blind, } \\
\text { placebo- } \\
\text { controlled }\end{array}$ & 150 & $28-30 \mathrm{mg} / \mathrm{kg}$ & 60 & $\begin{array}{l}\text { Improved liver function. } \\
\text { No improvement in symptoms or } \\
\text { histology. } \\
\text { Discontinued early (6yrs): significantly } \\
\text { risk of death, need for liver transplant or } \\
\text { development of varicies. }\end{array}$ \\
\hline
\end{tabular}


Table 2: Trials of immunosuppressants, antifibrinolytics, biological therapy and other agents in monotherapy in PSC

\begin{tabular}{|c|c|c|c|c|c|}
\hline Reference & Type of study & $\begin{array}{l}\text { No. of } \\
\text { patients }\end{array}$ & Therapy & Duration & Outcomes \\
\hline $\begin{array}{l}\text { Angulo et } \\
\text { al, 2000 } \\
{[182]}\end{array}$ & Pilot study & 21 & $\begin{array}{l}\text { Budesonide } \\
9 \mathrm{mg} \text { od oral }\end{array}$ & 1 year & $\begin{array}{l}\text { Improvement liver biochemistry. } \\
\text { No effect on Mayo risk score. } \\
\text { Significant worsening of osteoporosis } \\
\text { (femoral neck and lumbar spine). }\end{array}$ \\
\hline $\begin{array}{l}\text { Knox et al, } \\
1991[183]\end{array}$ & Open study & $\begin{array}{l}10 \text { (pre } \\
\text { cirrhotic) }\end{array}$ & $\begin{array}{l}\text { Methotrexate } \\
15 \mathrm{mg} / \text { week } \\
\text { oral, pulsed }\end{array}$ & 12 months & Improved liver function and histology \\
\hline $\begin{array}{l}\text { Knox et al, } \\
1994 \text { [184] }\end{array}$ & $\begin{array}{l}\text { Double-blind } \\
\text { placebo controlled } \\
\text { trial }\end{array}$ & 24 & $\begin{array}{l}\text { Methotrexate } \\
15 \mathrm{mg} / \text { week } \\
\text { oral, pulsed }\end{array}$ & 24 months & $\begin{array}{l}\text { Improvement in serum ALP. } \\
\text { No effect on other liver biochemistry, } \\
\text { liver histology, cholangiograms or } \\
\text { outcome. }\end{array}$ \\
\hline $\begin{array}{l}\text { Sandborn et } \\
\text { al, } 1993 \\
{[185]}\end{array}$ & Controlled trial & 35 & $\begin{array}{l}\text { Cyclosporine } \\
4 \mathrm{mg} / \mathrm{kg} / \text { day oral }\end{array}$ & 2 year $\mathrm{FU}$ & $\begin{array}{l}\text { No improvement in biochemistry or } \\
\text { histology. Controls associated UC. }\end{array}$ \\
\hline $\begin{array}{l}\text { Van Theil et } \\
\text { al, 1995 } \\
{[186]}\end{array}$ & Open study & 10 & $\begin{array}{l}\text { Tacrolimus bd } \\
\text { oral }\end{array}$ & 12 months & Improvement liver biochemistry \\
\hline $\begin{array}{l}\text { Olsson et al, } \\
1995 \text { [187] }\end{array}$ & $\begin{array}{l}\text { Double blind } \\
\text { placebo controlled } \\
\text { randomised study }\end{array}$ & 84 & $\begin{array}{l}\text { Colchicine } \\
1 \mathrm{mg} / \text { day oral }\end{array}$ & 36 months & $\begin{array}{l}\text { No effect on symptoms, liver } \\
\text { biochemistry, histology or survival. }\end{array}$ \\
\hline $\begin{array}{l}\text { LaRusso et } \\
\text { al, } 1988 \\
{[188]}\end{array}$ & $\begin{array}{l}\text { Randomized, } \\
\text { double-blind trial }\end{array}$ & 70 & $\begin{array}{l}\text { Penicillamine } \\
250 \mathrm{mg} \text { tds oral }\end{array}$ & 36 months & $\begin{array}{l}\text { No effect on symptoms, liver function, } \\
\text { histology, or survival. } \\
\text { Side effects in } 21 \% \text {-discontinued drug }\end{array}$ \\
\hline $\begin{array}{l}\text { Bharucha et } \\
\text { al, 2000 } \\
{[189]}\end{array}$ & Open pilot study & 20 patients & $\begin{array}{l}\text { Pentoxifylline } \\
400 \mathrm{mg} \text { qds oral }\end{array}$ & 1 year & $\begin{array}{l}\text { No effect on symptoms or liver } \\
\text { function tests }\end{array}$ \\
\hline $\begin{array}{l}\text { Duchini et } \\
\text { al, } 2000 \\
{[190]}\end{array}$ & Open label pilot trial & 4 & Cladribine oral & $\begin{array}{l}6 \text { months } \\
\text { ( } 24 \text { month } \\
\text { follow-up) }\end{array}$ & $\begin{array}{l}\text { Improvement in histology. } \\
\text { No effect on symptoms, liver } \\
\text { biochemistry, cholangiograms. }\end{array}$ \\
\hline $\begin{array}{l}\text { Angulo et } \\
\text { al, 2002 } \\
{[191]}\end{array}$ & Pilot study & 24 & $\begin{array}{l}\text { Pirfenidone } \\
2400 \mathrm{mg} \text { oral }\end{array}$ & 12 months & $\begin{array}{l}\text { No effect in liver biochemistry, } \\
\text { histology, cholangiogram, Mayo risk } \\
\text { score. }\end{array}$ \\
\hline $\begin{array}{l}\text { Angulo et } \\
\text { al, 1999 } \\
{[192]}\end{array}$ & Open study & 8 & $\begin{array}{l}\text { Nicotine } 6 \mathrm{mg} \\
\text { qds oral }\end{array}$ & 12 months & $\begin{array}{l}\text { No effect on liver function. } \\
\text { Frequent side effects. }\end{array}$ \\
\hline $\begin{array}{l}\text { Vleggaar et } \\
\text { al, 2001 } \\
{[193]}\end{array}$ & $\begin{array}{l}\text { Double blind } \\
\text { placebo-controlled } \\
\text { randomised cross- } \\
\text { over study }\end{array}$ & 12 & $\begin{array}{l}\text { Nicotine } \\
15 \mathrm{mg} / \text { day } \\
\text { transdermal } \\
\text { patch }\end{array}$ & 2 months & $\begin{array}{l}\text { No effect on symptoms or liver } \\
\text { biochemistry. }\end{array}$ \\
\hline $\begin{array}{l}\text { Epstein et } \\
\text { al, 2004 } \\
{[194]}\end{array}$ & Pilot study & 10 & $\begin{array}{l}\text { Etanercept } \\
25 \mathrm{mg} \\
\text { twice/week sc t }\end{array}$ & $\begin{array}{l}6-12 \\
\text { months }\end{array}$ & $\begin{array}{l}\text { Minimal improvement in pruritis only. } \\
\text { No effect on liver biochemistry or } \\
\text { cholangiograms. }\end{array}$ \\
\hline $\begin{array}{l}\text { Talwalkar et } \\
\text { al, 2005 } \\
{[195]}\end{array}$ & Pilot study & 30 & $\begin{array}{l}\text { Mycophenolate } \\
\text { mofetil } 1-3 g \\
\text { oral }\end{array}$ & 12 months & $\begin{array}{l}\text { Improved ALP. No effect on other } \\
\text { liver biochemistry or Mayo risk score }\end{array}$ \\
\hline $\begin{array}{l}\text { Talwalker et } \\
\text { al, 2007 } \\
{[196]}\end{array}$ & $\begin{array}{l}\text { Open labelled phase } \\
\text { II study }\end{array}$ & 16 & $\begin{array}{l}\text { Tacrolimus } \\
0.05 \mathrm{mg} / \mathrm{kg} \text { bd } \\
\text { oral }\end{array}$ & 1 year & $\begin{array}{l}\text { Improvement ALP. } \\
\text { Adverse side effects. }\end{array}$ \\
\hline $\begin{array}{l}\text { Hommes et } \\
\text { al, 2008 } \\
{[197]}\end{array}$ & $\begin{array}{l}\text { Double blind } \\
\text { placebo controlled } \\
\text { study }\end{array}$ & 10 & $\begin{array}{l}\text { Infliximab } \\
5 \mathrm{mg} / \mathrm{kg} \text { (weeks } \\
0,2,6,12,18 \\
\text { 24) intravenous }\end{array}$ & $\begin{array}{l}26 \text { weeks, } \\
\text { prematurely } \\
\text { halted }\end{array}$ & $\begin{array}{l}\text { no significant differences in liver } \\
\text { biochemistry at week } 18 \text { or } \\
\text { histological parameters at week } 26\end{array}$ \\
\hline $\begin{array}{l}\text { Angulo et } \\
\text { al, 2008 } \\
{[198]}\end{array}$ & Pilot study & 30 & $\begin{array}{l}\text { Silymarin } \\
140 \mathrm{mg} \text { tds oral }\end{array}$ & 12 months & $\begin{array}{l}\text { Improvement in liver biochemistry } \\
\text { (except bilirubin). }\end{array}$ \\
\hline $\begin{array}{l}\text { Mizuno et } \\
\text { al, 2010 } \\
{[199]}\end{array}$ & $\begin{array}{l}\text { Non-controlled } \\
\text { study }\end{array}$ & 7 patients & $\begin{array}{l}\text { Bezafibrate } \\
400 \mathrm{mg} / \text { day oral }\end{array}$ & $\begin{array}{l}8-27 \\
\text { months }\end{array}$ & $\begin{array}{l}\text { Improved liver biochemistry. } \\
\text { No effect on symptoms. Not assess } \\
\text { progression or survival. }\end{array}$ \\
\hline
\end{tabular}


Table 3: Combination therapy in PSC

\begin{tabular}{|c|c|c|c|c|c|}
\hline Reference & Type of study & $\begin{array}{l}\text { No. of } \\
\text { patients }\end{array}$ & Therapy & Duration & Outcomes \\
\hline $\begin{array}{l}\text { Lindor et al, } \\
1991 \text { [200] }\end{array}$ & $\begin{array}{l}\text { Historical } \\
\text { controlled trial }\end{array}$ & 12 & $\begin{array}{l}\text { Prednisolone } \\
10 \mathrm{mg} / \text { day and } \\
\text { colchicine } 0.6 \mathrm{mg} \text { bd }\end{array}$ & 24 months & $\begin{array}{l}\text { No benefit in liver biochemistry } \\
\text { or histology. Trend towards } \\
\text { improved survival. }\end{array}$ \\
\hline $\begin{array}{l}\text { Kyokane et } \\
\text { al, } 1994 \\
{[201]}\end{array}$ & Case report & $\begin{array}{l}1 \text { ?definite } \\
\text { PSC }\end{array}$ & $\begin{array}{l}\text { Methylprednisolone } \\
\text { and cyclosporine }\end{array}$ & unknown & $\begin{array}{l}\text { Improved cholangiogram and } \\
\text { pancreatography }\end{array}$ \\
\hline $\begin{array}{l}\text { Lindor et al, } \\
1996 \text { [202] }\end{array}$ & Pilot study & 19 & $\begin{array}{l}\text { Methotrexate } \\
0.25 \mathrm{mg} / \mathrm{kg} / \text { week and } \\
\text { UDCA } 13- \\
15 \mathrm{mg} / \mathrm{kg} / \text { day }\end{array}$ & 24 months & $\begin{array}{l}\text { No effect on symptoms or liver } \\
\text { biochemistry. Increased risks of } \\
\text { toxicity with MTX. }\end{array}$ \\
\hline $\begin{array}{l}\text { Schramm et } \\
\text { al, 1999 } \\
{[203]}\end{array}$ & Case series & 15 & $\begin{array}{l}\text { Azathioprine } \\
1.5 \mathrm{mg} / \mathrm{kg} / \text { day and } \\
\text { prednisolone } \\
1 \mathrm{mg} / \mathrm{kd} / \text { day (taper to } \\
10 \mathrm{mg} / \text { day) and } \\
\text { UDCA 500-750mg/day }\end{array}$ & $\begin{array}{l}41 \text { months } \\
\text { (median) }\end{array}$ & $\begin{array}{l}\text { Improved liver biochemistry and } \\
\text { histology. Adverse events in } 2 \\
\text { patients leading to withdrawal of } \\
\text { the drugs. }\end{array}$ \\
\hline $\begin{array}{l}\text { Van } \\
\text { Hoogstraten } \\
\text { et al, } 2000 \\
{[204]}\end{array}$ & $\begin{array}{l}\text { Double blind } \\
\text { randomised pilot } \\
\text { trial }\end{array}$ & 18 & $\begin{array}{l}\text { UDCA } 12 \mathrm{mg} / \mathrm{kg} / \mathrm{day} \\
\text { with no response at } 5 \\
\text { months, add } \\
\text { prednisone } 10 \mathrm{mg} \text { or } \\
\text { budesonide } 3 \mathrm{mg} \text { or } \\
9 \mathrm{mg} / \text { day }\end{array}$ & 2 month & $\begin{array}{l}\text { No benefit of combining } \\
\text { budesonide with UDCA. } \\
\text { Minimal short-term } \\
\text { improvements in liver } \\
\text { biochemistry and symptoms } \\
\text { with prednisolone and UDCA. }\end{array}$ \\
\hline $\begin{array}{l}\text { Stirling et al, } \\
2004 \text { [205] }\end{array}$ & $\begin{array}{l}\text { Randomised } \\
\text { controlled pilot } \\
\text { study }\end{array}$ & 25 & $\begin{array}{l}\text { UDCA } 13-15 \mathrm{mg} / \mathrm{kg} / \\
\text { day and } \\
\text { Mycophenolatemofetil } \\
1000 \mathrm{mg} \text { bd }\end{array}$ & 24 months & $\begin{array}{l}\text { No effect on liver biochemistry, } \\
\text { histology, cholangiograms. }\end{array}$ \\
\hline
\end{tabular}


Table 4: Antibiotics trials in PSC

\begin{tabular}{|l|l|l|l|l|l|}
\hline Reference & Type of study & $\begin{array}{l}\text { No. of } \\
\text { patients }\end{array}$ & Therapy & Duration & Outcomes \\
\hline $\begin{array}{l}\text { Davies et al, } \\
2008 \text { [207] } \\
\text { children }\end{array}$ & Pilot study & $\begin{array}{l}14 \\
\text { Vancomycin oral }\end{array}$ & 2 months & $\begin{array}{l}\text { Improvement in liver } \\
\text { biochemistry and symptoms. } \\
\text { Best results in those without } \\
\text { cirrhosis. }\end{array}$ \\
\hline $\begin{array}{l}\text { Silveria et al, } \\
2009 \text { [208] }\end{array}$ & Pilot study & 16 & $\begin{array}{l}\text { Minocycline 100mg bd } \\
\text { oral }\end{array}$ & 12 months & $\begin{array}{l}\text { Significant improvement in liver } \\
\text { biochemistry and Mayo risk } \\
\text { score. }\end{array}$ \\
\hline $\begin{array}{l}\text { Farkkila et al, } \\
2004 \text { [209] }\end{array}$ & $\begin{array}{l}\text { Randomized } \\
\text { controlled trial }\end{array}$ & 80 & $\begin{array}{l}\text { Metronidazole with or } \\
\text { without UDCA }\end{array}$ & 36 months & $\begin{array}{l}\text { Improved serum ALP and new } \\
\text { Mayo risk score with } \\
\text { combination therapy. No effect } \\
\text { on cholangiogram or disease } \\
\text { progression. }\end{array}$ \\
\hline
\end{tabular}


Table 5: Extrahepatic complications of PSC

\begin{tabular}{|c|c|}
\hline Pruritis & $\begin{array}{l}\text { - Exclude bile duct obstruction from a dominant stricture } \\
\text { - Exclude UDCA causing a paradoxical worsening of pruritis } \\
\text { - } 1^{\text {st }} \text { line: Cholestyramine or other resins. Effective in } 80 \text { to } 90 \% \text { of } \\
\text { patients, despite a limited evidence base } \\
\text { - } \text { 2 }^{\text {nd }} \text { line: Rifampicin. Although drug-induced hepatitis, liver dysfunction } \\
\text { and discolouration of bodily fluids limit its use }{ }^{129-130} \\
\text { - } \frac{3^{\text {rd }} \text { line: Naltrexone; Sertraline; Ondansetron }{ }^{130-134} \text {. Etanercept has also }}{\text { been shown to relieve pruritis in a study without this as its primary }} \\
\text { aim }^{135} \\
\text { Intractable pruritis is an indication for liver transplantation. }\end{array}$ \\
\hline Fatigue & $\begin{array}{l}\text { Exclude other causes including hypothyroidism, anaemia, diabetes, } \\
\text { depression, and medication } \\
\text { Management is supportive: } \\
\text { 1. Minimise factors exacerbating autonomic dysfunction and sleep disturbance }{ }^{123} \\
\text { 2. Provide psychological support to develop coping strategies }{ }^{123} \\
\text { Modafinil: can be effective in patients with primary biliary cirrhosis } \\
\text { (PBC) who have fatigue associated with prominent daytime somnolence, } \\
\text { but has not been studied in } \text { PSC }^{136} \\
\text { - Liver transplantation is not indicated for fatigue alone }\end{array}$ \\
\hline Malabsorption & $\begin{array}{l}\text { Prolonged cholestasis can lead to the malabsorption of fat and fat- } \\
\text { soluble vitamins. } \\
\text { Supplement vitamins A, E and K enterally in the presence of } \\
\text { steatorrhoea or laboratory evidence of malabsorption } \\
\text { Parenteral vitamin K in overt cholestasis and in the context of bleeding, } \\
\text { prior to invasive procedures such as sphincterotomy and/or stent } \\
\text { insertion at ERCP }\end{array}$ \\
\hline $\begin{array}{l}\text { Metabolic bone } \\
\text { disease }\end{array}$ & $\begin{array}{l}\text { - Increased risk of hepatic osteodystrophy in advanced liver disease } \\
\text { and/or overt cholestasis. Incidence between } 4 \text { and } 10 \% \text {. } \\
\text { Assess risk for osteoporosis in all PSC patients } \\
\text { Higher risk: longer duration of IBD, more advanced liver disease and post- } \\
\text { transplantation, especially within the first } 3 \text { months }{ }^{137-138} \\
\text { Established population risk factors for osteoporosis provide additional risk that } \\
\text { outweighs cholestasis-related risk } \\
\text { - Bone mineral density assessment (DEXA) at presentation } \\
\text { DEXA re-screening between } 1 \text { and } 5 \text { years depending on outcome, } \\
\text { degree of cholestasis and individual risk factors }{ }^{123,137} \\
\text { Measures to prevent and treat hepatic osteodystrophy (based on } \\
\text { evidence from PBC) including calcium and vitamin D supplements; } \\
\text { bisphosphonates; hormone replacement therapy in post-menopausal } \\
\text { females } 3{ }^{139-140}\end{array}$ \\
\hline
\end{tabular}




\section{Table 6: Indications for Liver Transplantation in PSC}

\begin{tabular}{|l|ll|}
\hline $\begin{array}{l}\text { Indications similar to } \\
\text { other end stage liver } \\
\text { disease }\end{array}$ & $\begin{array}{l}\text { - } \\
\text { - }\end{array}$ & $\begin{array}{l}\text { Complications of portal hypertension } \\
\text { Impaired quality of life }\end{array}$ \\
\hline $\begin{array}{l}\text { Special indications in } \\
\text { PSC despite a low } \\
\text { priority MELD (less than } \\
\text { or equal to 17) or UKELD } \\
\text { (less than or equal to 49) } \\
\text { score }\end{array}$ & $\begin{array}{l}\text { - } \\
\text { - }\end{array}$ & $\begin{array}{l}\text { Intractable pruritis } \\
\text { Recurrent or refractory bacterial cholangitis } \\
\text { operative repair }\end{array}$ \\
& $\begin{array}{l}\text { Uncontrolled peristomal variceal bleeding } \\
\text { Limited stage peripheral or hilar cholangiocarcinoma (in the } \\
\text { context of a clinical trial with careful selection of patients } \\
\text { and neo-adjuvant therapy) } \\
\text { are decided } 16 \text {. The merits of theses cases individual basis. }\end{array}$ \\
\hline
\end{tabular}

